\title{
SISTEMAS ELEITORAIS E DEMOCRACIA REPRESENTATIVA NO LIMIAR DO CONSTITUCIONALISMO PORTUGUÊS
}

\section{ELECTORAL SYSTEMS AND REPRESENTATIVE DEMOCRACY IN THE THRESHOLD OF PORTUGUESE CONSTITUTIONALISM}

\author{
José Domingues \\ Universidade Lusiada - Norte (Porto) \\ Manuel Monteiro \\ Universidade Lusiada - Norte (Porto)
}

\begin{abstract}
SUMÁRIO: I. INTRODUÇÃO.- II. O SISTEMA ELEITORAL CONSUETUDINÁRIO.III. O NOVO SISTEMA ELEITORAL VINTISTA.- 1 . O modo de eleição dos Deputados.- 2. A modalidade do voto.- 3. O critério de atribuição dos mandatos.IV. CONCLUSÃO.
\end{abstract}

Resumo: O parlamento (Cortes, para o caso português sub judice) é o símbolo supremo da democracia representativa. Na base da sua formação está a eleição dos representantes por parte da comunidade política. Este trabalho vai centrar-se no modo de eleição dos representantes às primeiras Cortes constituintes portuguesas, que são convocadas para a elaboração da Constituição de 1822. No ano da revolução de 1820 vai dar-se o embate entre o velho sistema eleitoral medieval e o novo sistema eleitoral vintista, que acabou por definir a trajetória a seguir pela representação política e marcou de forma indelével o parlamentarismo português até à actualidade. Tendo por base essa liça entre os dois processos eleitorais, este artigo pretende aferir a evolução da teoria do voto e do direito eleitoral no espaço cronológico português de 1820 a 1822.

\begin{abstract}
Parliament ("Cortes", for the Portuguese case sub judice) is the supreme symbol of representative democracy. At the cornerstone of its formation is the election of the representatives by the political community. This work will focus on the way of electing representatives to the first Portuguese constituent "Cortes", which are called for the elaboration of the Constitution of 1822. In the year of the revolution of 1820 there will be a clash between the old medieval electoral system and the new vintista electoral system, which ended up defining the course to be followed by political representation and marked the Portuguese parliamentarism indelibly until now. Based on this fray between the two electoral processes, this article intends to assess the evolution of the theory of voting and electoral law in the Portuguese chronological space from 1820 to 1822.
\end{abstract}

Palavras chave: Democracia Representativa, Parlamento, Eleições, Portugal, Século XIX. 
Key Words: Representative Democracy, Parliament, Elections, Portugal, XIX Century.

\section{INTRODUÇÃO.}

Os sistemas eleitorais e a representação política são um ideal arquisecular que continua a ocupar um lugar de destaque e se mantém bem aceso como tema de preferência no seio do pensamento político-constitucional hodierno. A grande controvérsia da actualidade -que não se apresenta fácil de solucionar ou, sequer, de remediar- oscila entre o seu incontestável desempenho como factor legitimador do Estado de Direito Democrático, por um lado, e a responsabilidade que se lhe possa vir a imputar na debilitação da própria democracia, por outro lado. A conciliação da democracia com a representação continua a ser o grande desafio para a esmagadora maioria dos regimes politicos contemporâneos ${ }^{1}$.

A designação -democracia representativa- surgiu do casamento entre dois termos, à partida, incompativeis -representação e democracia- feito por Alexander Hamilton, numa carta dirigida em 1777 ao governador Morris ${ }^{2}$. Sem embargo, a ideia de uma representação politica e a existência de governos representativos é muito anterior e terá sido uma das grandes conquistas da Idade Média europeia: "the idea of political representation -assevera Joseph Strayer- is one of the great discoveries of medieval governments; the Greeks and the Romans may have made a few tentative moves in this direction, but they have never explored the technique thoroughly"3.

A Igreja foi pioneira a introduzir a representação politica na Europa, nas palavras de Kenneth Pennington, "the jurisprudence of representation entered European society trough the Church"4. Neste sentido, Julien Théry, afirma "Athènes fut le cadre d'une démocratie directe et Rome d'une république censitaire. Mais les civilisations de l'Antiquité, pas plus qu'aucune autre avant la Chrétienté latine du XIIe siècle, n'ont jamais connu la notion de représentation politique. L'idée qu'un seul, ou un nombre restreint d'individus, puisse agir pour un plus grand nombre, se substituer légitimement aux gouvernés pour exercer le pouvoir en leur nom, ou encore représenter les gouvernés auprès des gouvernants, est une création

1 V. g., Pierre Rosanvallon, La Contre-Démocratie: La politique à l'âge de la défiance, Paris, Seuil, 2006; Nadia URBINATI, "Representative democracy and its critics", in Sonia Alonso et al. (eds.), The Future of Representative Democracy, Cambridge University Press, 2011, pp. 1-27; Pierre Rosanvallon, Le Bon Gouvernement, Paris, Seuil, 2015; David VAn ReYBroucK, Against Elections: The Case for Democracy, Translated by Liz Waters, London, 2016; Jason BRENNAN, Against Democracy, Princeton University Press, 2016.

2 John Keane, Vida e Morte da Democracia, tradução de Nuno Castello-Branco Bastos, Lisboa, Edições 70, 2009, p. 186: “Alexander Hamilton (1756-1804) foi, porventura o primeiro americano a conseguir que as palavras representação e democracia dessem o abraço uma à outra e, em dada ocasião, chegou até a empregar uma locução nova em folha, "democracia representativa", claramente sem fazer a mínima ideia do que estava a dizer".

3 Joseph STRAYer, On the Medieval Origins of the Modern State, Princeton University Press, 1970, pp. 65-67. Peter PUlzer, Political Representation and Elections in Britain, Routledge, 2010 p. 13: "Parliaments are a legacy of the feudal Middle Ages".

${ }^{4}$ Kenneth Pennington, "Politics in Western Jurisprudence", in The Jurists' Philosofy of Law from Rome to the Seventeenth Century, Andrea PADOVANI and Peter G. STEIN (eds.), Dordrecht, Springer, 2007, pp. 186 e ss. 
du Moyen Âge occidental. Elle est née du principe médiéval selon lequel tout pouvoir légitime doit recueillir l'assentiment de ceux sur qui et au nom de qui il s'exerce"s.

A base do ideal medievo de se enviarem delegados às assembleias representativas, que tivessem poder bastante e suficiente para vincular toda a comunidade eleitoral, assenta no principio do Q. O. T (quod omnes tangit) ou principio do consentimento romano, segundo o qual, o que a todos importa por todos deve ser aprovado ${ }^{6}$. Esta máxima latina vai contagiar, de imediato, o poder político secular e, a partir do século XIII, deu origem às assembleias representativas medievais -Cortes, Parliaments, Etats-généraux, Diet, Sejm, Rigsdag, Riksdag, Generallandtag- convocadas pelos vários líderes europeus nos seus respectivos territórios de acção politica ${ }^{7}$.

Todo o cerne da democracia representativa ou indirecta, desde esses recuados tempos medievais, assenta no exercício do poder político pelo conjunto dos membros da coletividade (potestas ou soberania popular), através de órgãos representativos. O que pressupõe que os titulares desses órgãos representativos sejam escolhidos pelos e, em princípio, entre os membros da própria comunidade. Ao lado da máxima da jusromanística de que "o que a todos diz respeito, por todos deve ser aprovado" implementou-se a máxima de que "aqueles que exercem o poder em nome de todos, por todos devem ser eleitos”.

Em suma, são as estruturas eleitorais que fazem com que os governos sejam representativos e espelham o grau de organização politica da própria comunidade. Por isso, em 1832, Ferreira Borges entendia que "o grande, o único poder político constitucional é o eleitoral, é ele só a fonte de todos e o princípio motor da organização social's. O que nos conduz ao mais elementar e enigmático axioma que está na origem e fundamento de qualquer democracia representativa: (i) a democracia directa torna-se inviável em sociedades humanas numerosas e complexas e em espaços territoriais extensos, impondo-se-lhe a democracia representativa como a melhor alternativa, $i$. e., a representação nasceu contra o

\footnotetext{
5 Julien THÉRY, "Moyen Âge”, in Dictionnaire du Vote, dir. Pascal Perrineau e Dominique Reynié, Paris, Presses universitaires de France, 2001, pp. 667-678 (667).

6 "Quod omnes similiter tangit, ab omnibus comprobetur" (Cód. 5.59.5.2). No Corpus de Justiniano o Q.O.T. é um principio sem qualquer significado constitucional, exclusivo de direito privado e de assuntos entre particulares, que foi adaptado à causa pública e aos assuntos de Estado pelo talento dos jurisperitos da Idade Média. Kenneth PENNINGToN, "Representation in Medieval Canon Law", in The Jurist 64, 2004, p. 361: "The jurisprudential concept of "representatio" as agency is, perhaps, one of the most important contributions that the medieval jurists of the Ius commune made to Western legal thought".
}

7 O principio do Q. O. T. foi usado para convocar parlamentos, primordialmente, pelo imperador Frederico II em 1231 e 1244, por Eduardo I de Inglaterra em 1295, por Filipe IV de França em 1302; e consta positivado nas Ordenações da Justiça de Florença de 1293 e no Liber Sextus de Bonifácio VIII de 1298 (VI 5.[13].29). Cf. David STASAVAGE, "Representation and Consent: Why They Arose in Europe and Not Elsewhere", in Annual Review of Political Science 19, 2016, pp. 145-162; Orazio CoNDORELLI, "Quod omnes tangit, debet ab omnibus approbari". Note sull'origine e sull'utilizzazione del principio tra medioevo e prima ètat moderna”, in Ius Canonicum 53, 2013, pp. 101-127; Bernard MANin, The Principles of Representative Government, Cambridge University Press, 1997, p. 87; Arthur P. MonAhan, Consent, Coercion, and Limit: The Medieval Origins of Parliamentary Democracy, Leiden, Brill, 1987, pp. 97 e ss; Hanna PITKIN, The Concept of Representation, Berkeley, University of California Press, 1967, p. 85.

8 José Ferreira Borges, Cartilha do Cidadão Constitucional Dedicada à Mocidade Portuguesa, Londres, Hansard, 1832, p. 14. 
autogoverno do próprio povo9; (ii) mas o ditoso consenso na escolha dos titulares para os órgãos representativos nunca foi, nem será, tarefa fácil e vulgar, i. e., o ideal de uma plausivel unanimidade entre os membros da comunidade eleitoral apresenta-se como uma quimera cada vez mais longinqua e inatingivel.

Por isso, ao mesmo tempo que a democracia indirecta se foi impondo à democracia directa, também o encanecido princípio da aclamação, do consenso total ou da unanimidade foi posto em causa e acabou por ser suplantado pelo princípio da maioria. Contrariando o mais expectável, a regra da maioria rapidamente acabaria por se converter numa armadilha ardilosa, pejada de perigos para a democracia eleitoral. Na verdade, a vontade maioritária de um corpo eleitoral pode não corresponder à escolha dos melhores e mais aptos candidatos, colocando em causa a almejada representação política. Para além da plausivel "ditadura da maioria", o cisma, o caciquismo, a fraude e a manipulação dos resultados eleitorais são perigos eminentes que, não raro, surgem ligados a decisões democráticas maioritárias.

Em resposta a este complexo desafio de ter que se escolher os representantes políticos da respectiva comunidade, através do princípio da maioria, surge a teoria do voto e, desde muito cedo, foram pensadas e inventadas diversas soluções eleitorais - $v$. g., maior et sanior pars, maiorias agravadas, voto secreto, colégios eleitorais, voto capacitário, voto censitário, voto direto, voto indireto em vários graus eleitorais, conjugação com processos de sorteio, etc.-. Mais uma vez, não terá sido por mero acaso que os primeiros escritos sobre a teoria do voto, que chegaram até aos nossos dias, tenham surgido em plena Baixa Idade Média. Tendo em conta que a temática das eleições não faz parte do imenso legado democrático da Grécia Antiga -onde a escolha era feita por mero sorteio ${ }^{10}$ ou proposta binária- Iain McLean, assevera que "we should not be surprised to

9 Thomas PAIne, The Rights of Man. Part the Second. Combining Principle and Practice, London, 1792, pp. 33-34: "What Athens was in miniature, American will be in magnitude (...) It is impossible to conceive a system of government capable of acting over such an extent of territory, and such a circle of interests, as is immediately produced by the operation of representation. France, great and populous as it is, is but a spot in the capaciousness of the system. It is preferable to simple democracy even in small territories. Athens, by representation, would have outrivalled her own democracy". Pablo Lucas Murillo DE LA CuEva, "Encuesta Sobre la Representación Política", in Teoria y Realidad Constitucional 34, 2014, p. 24: “a democracia ou é representativa ou não é democracia. La democracia directa no es viable como forma politica del Estado y tampoco es deseable que lo sea porque, al margen de las dificultades prácticas para articularla, no permite la reflexión imprescindible que si hacen posible los mecanismos de la representación politica”. Salvo as manifestações de democracia directa que, na actualidade, ainda subsistem em "el Pirineo, en Teruel, en algunos cantones suizos, parroquias portuguesas, inglesas o suecas y en comunas rurales de Austria y Alemania" (cf. Estela GILBAJA CABRERO, "Democracia Directa y Concejo Abierto. El Concejo Abierto en Castilla y León", in Revista General de Derecho Constitucional 16, 2013, p. 8). O caso português consta consignado no próprio texto constitucional: "A lei pode determinar que nas freguesias de população diminuta a assembleia de freguesia seja substituida pelo plenário dos cidadãos eleitores" (art. $245^{\circ}$, n. $^{\circ} 2$ da CRP).

10 Cf. Augustin Berthout, "Le sort est un dieu. Aux origines du tirage au sort politique à Athènes", in Jus Politicum 17, pp. 715-778 [Disponivel em: http://juspoliticum.com/article/Lesort-est-un-dieu-Aux-origines-du-tirage-au-sort-politique-a-Athenes-1147.html (consultado no dia 28 de Julho de 2017)]. 
find intelligent discussion of voting schemes first appearing in the West in the Middle Ages"11.

Neste lapso cronológico de vários séculos vão surgir dois pensadores que são considerados os precursores do pensamento liberal dos finais do século XVIII -a idade de ouro da teoria do voto- e se antecipam ao trabalho de "Condorcet, Borda and Dodgson by over 500 years"12. Trata-se do catalão, natural de Palma de Maiorca, Ramon Llull (c. $1232-1316)^{13}$ e do alemão Nicolau de Cusa (1401$1464)^{14}$.

Em Portugal, num dos momentos mais marcantes para a sua história eleitoral, vai dar-se o embate entre o velho sistema de voto oriundo da Idade Média e a necessidade de se implantar um novo sistema de voto, seguindo de perto as pegadas das nações europeias consideradas constitucionais (nomeadamente, a vizinha Espanha). Com este singelo estudo pretendemos aproximarmo-nos um pouco mais desse marco miliário eleitoral, colocado no limiar do constitucionalismo moderno, apôs a Revolução Liberal de 24 de Agosto de 1820, na cidade do Porto. O novo sistema eleitoral vintista sairá vitorioso, vindo a ser definitivamente constitucionalizado na primeira Constituição escrita portuguesa, aprovada a 23 de Setembro de 1822. A aprovação desta Constituição acaba por nos servir de data limite ad quem para este trabalho e só a título meramente esporádico e exemplificativo nos referiremos a monumentos posteriores, v. g., a lei de 4 de Junho de 1824 e o decreto de 3 de Maio de 1828.

Pelo que nos foi possivel apurar, a liça travada nos primeiros anos da década de vinte do século XIX, entre o velho e o novo sistema eleitoral, tem passado praticamente desapercebida. Desde logo, porque são muito escassos os subsídios documentais conhecidos e bastante parcos e incompletos os estudos dedicados ao velho sistema de eleição dos procuradores às Cortes, que vinha do período mediévico luso15. Também, por outro lado, "em termos de produção historiográfica,

11 Iain MCLEAN, "The Borda and Condorcet principles - Three medieval applications", in Social Choice and Welfare 7/2, 1990, p. 107; Iain MCLEAN e Arnold B. URKEN, Classics of Social Choice, University of Michigan Press, 1995, pp. 1-2.

12 Iain MCLEAN, “The Borda and Condorcet principles - Three medieval applications”, op. cit., p. 107.

13 Os escritos de Ramon Llull sobre eleições: Artifitium electionis personarum (c. 1274-1283); En qual manera Natana fo eleta a abadessa (c. 1283); e De arte eleccionis (1299) [Disponiveis em: https://www.math.uni-augsburg.de/htdocs/emeriti/pukelsheim/llull/ (consultado no dia 26 de Fevereiro de 2017)]. Cf. Josep M. Colomer, "Ramon Llull: from 'Ars Electionis' to social choice theory", in Social Choice and Welfare 40/2, 2013, pp. 317-328 DOI: 10.1007/s00355-011-0598-2 [Disponivel em: https://link.springer.com/article/10.1007/s00355-011-0598-2 (consultado no dia 26 de Fevereiro de 2017)]; Iain MCLEAN, Haidee LORREY e Josep COLOMER, "Social Choice in Medieval Europe", in Journ@l Electronique d'Histoire des Probabilités et de la Statistique 4/1, 2008 [Disponivel em: http://www.jehps.net/juin2008/McLeanLorreyColomer.pdf (consultado no dia 26 de Fevereiro de 2017)]

14 O escrito de Nicolaus de Cusanus (Niklaus von Kues) sobre eleições: On Catholic Harmony, Livro III, Capitulo 37 (1434), traduzido (para Inglês) e publicado por Iain McLEAN e Arnold B. URKEn, Classics of Social Choice, op. cit., pp. 77-78. Cf. Iain MCLEAN, Haidee LoRREY e Josep Colomer, "Social Choice in Medieval Europe", op. cit..

15 Armindo de SousA, "As Cortes de Leiria-Santarém de 1433", in O Parlamento Medieval Português e Outros Estudos, Porto, Fio da História, 2014, p. 39 e pp. 139-140 nota 32; Maria Helena da Cruz Coelho, "Les Còrtes Portugaises au Moyen Âge: Les procureurs des communes", in Diana Repeto García (coord.), Las Cortes de Cádiz y la Historia Parlamentaria, Cádiz, 
referente à primeira metade do século XIX, o tema das eleições vive praticamente "órfão", não existindo investigações de vulto sobre um objeto de estudo de tão grande relevância"16.

Nas linhas que se seguem propomo-nos abordar esses dois sistemas eleitorais em debate no limiar do constitucionalismo português: (II) o sistema tradicional que vinha dos tempos primordiais da monarquia e se tinha interrompido com a última reunião parlamentar, em 1697/98; (III) o novo sistema eleitoral vintista, cujo percurso inicial é amplamente seguidor da Constituição espanhola de Cádis de 1812. A partir desse cotejo poder-se-ão inferir as possíveis afinidades e divergências e formar alguns juízos. A pergunta de fundo que deixamos para tentar responder em conclusão (IV) é esta: será que o sistema eleitoral implantado pelo constitucionalismo liberal português é totalmente inédito ou ainda pode ser considerado tributário, pelo menos em alguns aspectos, da tradição eleitoral oriunda da Idade Média portuguesa?

Sem quaisquer pretensões de caso julgado e muito menos de esgotar ou, sequer, analisar todas as possibilidades deste mega tema, na tentativa de encontrar uma resposta satisfatória a este debate -para além da bibliografia mais autorizada e indispensável, que nos foi possivel compulsar- tentamos consultar algumas fontes documentais coevas para cada um dos sistemas eleitorais em exame: v.g., capítulos de Cortes, cartas régias convocatórias, procurações e actas municipais de eleição dos procuradores às Cortes, para o sistema tradicional; legislação eleitoral vintista, projecto da Constituição de 1822, texto da Constituição de 1822, Diários das Cortes Gerais Extraordinárias e Constituintes de 1821/22, alguns debates políticos da época e a principal doutrina em voga, para o sistema vintista.

Universidad de Cádiz, 2012, pp. 723-736; António de OLIVEIRA, "A República e as Repúblicas", in
O poder local em tempo de Globalização: uma história e um futuro, Coimbra, Imprensa da
Universidade e CEFA, 2005, p. 36, n. 94; Isabel GRAES, Contributo para um Estudo Histórico-
Jurídico das Cortes Portuguesas entre 1481 e 1641, Coimbra, Almedina, 2005, pp. 319-329;
Francisco Ribeiro da SILVA, "Os Concelhos e as Cortes Seiscentistas Portuguesas: representação e
intervenção (o caso do Porto)", in O Municipio no Mundo Português, Funchal, 1998, pp. 65-70;
Francisco Ribeiro da Silva, "O Porto e as Cortes no Século XVII ou os Concelhos e o Poder Central
em Tempos de Absolutismo", in Revista da Faculdade de Letras - História 10, Porto, 1993, pp. 9-
68; Francisco Ribeiro da SILVA, "A Participação do Porto nas Cortes de Lisboa de 1619", in Boletim
Cultural da Câmara Municipal do Porto 1, 1983, pp. 108-114; José Baptista BARREIROS, "A
propósito da aclamação de D. João IV em Braga", in O Distrito de Braga 3/1-2, Braga, 1964, pp.
233-235; Paulo MÉREA, "O Poder Real e as Cortes", in Estudos de Filosofia Jurídica e de História
das Doutrinas Politicas, Lisboa, Imprensa Nacional-Casa da Moeda, 2004, pp. 252-253 (1.a edição,
Coimbra, Coimbra editora, 1923); Henrique da Gama BARROs, História da Administração Pública
em Portugal nos Séculos XII a XV, Tomo I, Lisboa, Imprensa nacional, 1885, pp. 567-577; Visconde
de SANTARÉm, Memorias para a Historia e Theoria das Cortes Geraes que em Portugal se celebrarão
pelos tres estados do reino ordenadas e compostas neste anno de 1824, Parte I, Lisboa, na
Impressão Regia, 1827, pp. 8-14.

16 Sandra Coelho, "OO Negócio da Urna»: as eleições de 1842", in Ler História 68, 2015 [Disponivel em: https://lerhistoria.revues.org/1731 (consultado no dia 30 de Março de 2017] (DOI: $10.4000 /$ lerhistoria.1731). 


\section{O SISTEMA ELEITORAL CONSUETUDINÁRIO.}

Portugal, a partir das Cortes de Leiria de 1254, assume-se como um dos países pioneiros do parlamentarismo europeu ${ }^{17}$. Não surpreende, por isso, que o debate político do século XIX -à semelhança do que tinha ocorrido na vizinha Espanha18 - tenha chamado à colação as Cortes tradicionais, que vinham dos primórdios medievais e se interromperam no final do século XVII -a última reunião ocorreu em Lisboa, nos anos de 1697/98-. Este não é o momento oportuno para a querela que coloca em confronto o parlamento medieval e o parlamento oitocentista. Para o nosso propósito basta: (i) constatar que existiu esse debate político no período entre 1820-1822, sendo certo que, curiosamente, o novo parlamento manteve a mesma designação do velho parlamento ${ }^{19}$; (ii) ter

17 As Cortes de Leão de 1188 foram consideradas pela UNESCO como "o testemunho documental mais antigo do sistema parlamentar europeu". Em Inglaterra, as primeiras evidências de o rei convocar representantes do povo ao parlamento datam de 1254 (representatives of the counties) e 1265 (representatives of the boroughs); em França, os Estados Gerais reúnem pela primeira vez no ano de 1302; na Escócia, o primeiro Parlamento data de 1326; na Polónia, o primeiro Sejm reúne em 1399; nos Países Baixos, os primeiros Estados Gerais datam de 1406; na Dinamarca, o Rigsdag reúne pela primeira vez em 1468; e o Riksdag da Suécia em 1527. Cf. Jan Luiten VAN ZANDEN, Eltjo BURINGH and Maarten BOSKER, "The Rise and Decline of European Parliaments, 1188-1789", in The Economic History Review 65/3, 2012, pp. 835-861 [Disponivel em: http:/ / onlinelibrary.wiley.com/doi/10.1111/j.1468-0289.2011.00612.x/abstract (consultado no dia 18 de Agosto de 2017)]; Paul BRAND, "Parliament of England to 1307: The Development of Parliament, 1215-1307", in Clive Jones (ed.), A Short History of Parliament: England, Greta Britain, the United Kingdom, Ireland and Scotland, The Boydell Press, 2009, pp. 10-11.

18 V. g., Antoni SÁNCHEZ CARCElÉn, "Reivindicar el Pasado para Transformar el Presente y Legitimar la Revolución Constitucional: Historicismo y Diputados Catalanes en las Cortes de Cádiz", in Historia Contemporánea 51, 2015, pp. 543-575 [Disponivel em: http://www.ehu.eus/ojs/index.php/HC/article/view/14724C: \Users \Manuel

Monteiro\Downloads \www.historiaconstitucional.com (consultado no dia 10 de Março de 2017)]; Brendon Westler, "Between Tradition and Revolution: The Curious Case of Francisco Martínez Marina, the Cádiz Constitution, and Spanish Liberalism", in Journal of the History of Ideas 76/3, 2015, pp. 393-416; Faustino MARTINÉZ MARTINÉZ, "Jovellanos y sus Reflexiones sobre la constitutción, las leyes, usos y costumbres de Castilla", in Historia Iuris: Estudios dedicados al profesor Santos M. Coronas González, vol. II, Universidad de Oviedo Ediciones, 2014, pp. 919-938; Carlos Rodríguez LóPez-BreA, "Don Pedro Inguanzo y Rivero, un Canonigo Anti-Ilustrado en las Cortes de Cádiz", in Historia Constitucional 14, 2013, pp. 77-91 [Disponivel em: http://www.historiaconstitucional.com (consultado no dia 10 de Março de 2017)]; Faustino MARTINÉz MARTINÉZ, "Alfonso X en Cádiz. Visión constitucional de un monarca del Medievo (I) (II)", in Cuadernos de Historia del Derecho 17, 2010, pp. 49-102 e 19, 2012, pp. 99-203 [Disponivel em: https://revistas.ucm.es/index.php/CUHD (consultado no dia 10 de Março de 2017)]; Carlos GARRIGA ACOSTA, "Cabeza moderna, cuerpo gótico. La Constitución de Cádiz y el orden jurídico", in Anuario de Historia del Derecho Español 81, 2011, pp. 99-162 [Disponivel em: http://www.boe.es/publicaciones/anuarios_derecho/anuario.php?id=H_2011_ANUARIO_DE_HIS TORIA_DEL_DERECHO_ESPA\%D1OL (consultado no dia 10 de Março de 2017)]; Ignacio Fernández Sarasola, El Pensamiento Politico de Jovellanos. Seis Estudios, Oviedo, Editorial In Itinere, 2011 [Disponivel em: http://www.fundacioncardin.es/bibliotecamaliaya/content/elpensamiento-pol\%C3\%ADtico-de-jovellanos-seis-estudios (consultado no dia 10 de Março de 2017)].

19 Não será despiciendo que, v. g., a propósito da instalação das Cortes Constituintes de 1821, tenha ficado registado: "Hum povo illustre que vê resurgir a publica representação de seus direitos, depois de 122 annos de esquecimento e abandono da sua primaria prerogativa" (Diário do Governo n. ${ }^{\circ}$ 23, Sexta Feira, 26 de Janeiro de 1821). "Aprontar a copiosa collecção das antigas Cortes portuguezas" foi uma das preocupações das Cortes Extraordinárias e Constituintes de $1821-c f$. Henrique da Gama BARros, História da Administração Pública em Portugal nos Séculos XII a XV, Tomo III, 2. ${ }^{\text {a }}$ edição dirigida por Torquato de Sousa Soares, Lisboa, Livraria Sá da Costa Editora, 
em conta que pelo facto de o parlamento medieval ser uma assembleia estamental, não obsta a que possa ser considerado um órgão representativo da comunidade política da sua época -estruturada em estamentos ou classes-e, por esse mesmo facto, antecedente equiparável, mutatis mutandis, ao parlamento moderno ${ }^{20}$.

Sem embargo, não pretendemos confundir ou transpor realidades conceptuais de um tempo para outro. Cada uma delas deve ser recuperada, estudada e entendida no tempo a que pertence e dentro do contexto que lhe é propício. Tendo sempre estas cautelas como pano de fundo, nada obsta a que exista um fio condutor entre determinadas instituições jurídico-politicas. Desde logo, porque o sistema eleitoral da Idade Média portuguesa -que espelha as condicionantes e idiossincrasias do seu tempo- acabou por se repercutir no século XIX. A este propósito, em sintonia com Bernard Manin, importa ter em linha de conta que "there are good grounds for thinking that the electoral techniques employed by representative governments had their origins in medieval elections, both those of "Assemblies of Estates" and those practiced by the Church (rather than in the elections of the Roman republic, for example)"21.

$\mathrm{Na}$ Súplica da Constituição (1808), um grupo de intelectuais portugueses (o chamado grupo francês) solicita a Napoleão Bonaparte a outorga de uma Constituição idêntica à do grão-ducado de Varsóvia, mas "com a unica differença de que os representantes da nação sejam eleitos pelas camaras municipaes, a fim de nos conformarmos com os nossos antigos usos"22. Esta pretensão, de "ressuscitar" as Cortes tradicionais portuguesas e recuperar a prática eleitoral ligada à representação política de antanho, manter-se-á bem acesa até à revolta

1946, pp. 193-195 nota 1- processo ainda em aberto e que, pouco a pouco, vai sendo levado a cabo pelo Centro de Estudos Históricos da Universidade Nova de Lisboa. Por outro lado, torna-se bem notório o incremento que a Revolução de 1820 veio trazer ao estudo do parlamento medieval português - $c f$. Armindo de SousA, "As Cortes Medievais Portuguesas - Panorama Bibliográfico", in O Parlamento Medieval Português e Outros Estudos, Porto, Fio da História, 2014, pp. 223-234-.

20 V. g., Armindo de SousA, "O Parlamento Medieval Português - Perspectivas novas", in $O$ Parlamento Medieval Português e Outros Estudos, Porto, Fio da História, 2014, pp. 278-279: "as Cortes Medievais foram ou não olhadas e aceites como Assembleias Representativas da Nação? O rei e os súbditos contemplaram ou não as suas decisões como vontade colectiva do País? A resposta é inquestionavelmente afirmativa"; Peter BLICKLE, "Representing the 'common man' in old European parliaments", in Actes del 53è Congrés de la Comissió Internacional per a l'Estudi de la Història de les Institucions Representatives i Parlamentàries I, J. Sobrequés, J. Agirreazkuenaga, M. Morales, M. Urquijo i M. Cisneros (coords.), Barcelona, 2005, p. 132: "The crucial difference between Old European and modern parliaments is that today the legislative functionis an integral part of parliament and that representation has been extended from the estates to general representation of all citizens as ensured by periodic elections". Bernard MANIN, The Principles of Representative Government, op. cit., p. 86: "Some historians stress the differences between the medieval "Assemblies of Estates" and the representative assemblies that became the loucus of power in the wake of the three great revolutions. The differences are indeed substantial. However, they should not obscure the elements of continuity".

21 Bernard MANin, The Principles of Representative Government, op. cit., p. 86.

22 Simão José da Luz SoRIANo, Historia da Guerra Civil e do Estabelecimento do Governo Parlamentar em Portugal comprehendendo a historia diplomatica, militar e politica d'este reino desde 1777 até 1834, Segunda Época: Guerra da Península, tomo I, Lisboa, Imprensa Nacional, 1870, pp. 212-214 [Disponivel em: http://purl.pt/12103 (consultado no dia 8 de Março de 2017)]. 
liberal de 24 de Agosto de $1820^{23}$. E foi a solução que surgiu logo à cabeça dessa revolta ${ }^{24}$.

A Regência do Reino, que governava em nome de D. João VI desde 1810 e estava sediada em Lisboa, tentou adiantar-se à Junta Provisional do Governo Supremo do Porto, sediada no Porto, convocando à pressa os três "estados" do reino (clero, nobreza e povo) a Cortes. Em proclamação do dia 29 de agosto de 1820 os governadores do reino invocaram a ilegitimidade da Junta portuense para convocar as Cortes -que "sempre seriam ilegais quando não fossem chamadas pelo soberano"- e assumiram-se como os "únicos depositários legitimos da autoridade régia, na ausência do nosso amado soberano", resolvendo, por isso, "adotar, em seu real nome, a resolução de convocar as Cortes" como o "meio legal de atender às queixas e desejos da Nação".

Para esse feito, por portaria do dia 1 de setembro desse ano, nomearam uma comissão preparatória das Cortes, formada por D. Frei Patrício da Silva (arcebispo de Évora), Luís António Furtado de Castro do Rio de Mendonça e Faro (conde de Barbacena), Matias José Dias Azedo (tenente-general conselheiro de guerra), António José Guião (desembargador) e Tomás da Silva Monteiro (desembargador). O conde de Barbacena alegou moléstias que o impediam de assumir tal compromisso, por isso, em portaria de 4 de setembro, foi dispensado e para o seu lugar foi nomeado Joaquim José Ferreira Gordo; no mesmo diploma, para secretário foi nomeado Manuel Borges Carneiro.

Os governadores do reino, no dia 6 de Setembro, dirigiram uma proclamação ao exército assegurando que "acabam de convocar côrtes e trabalham com a maior actividade em accelerar o seu ajuntamento; brevemente vereis reunidos os tres estados do reino, conforme as leis fundamentaes da nossa monarchia; é esse o unico meio legal de consultar os votos da nação, de attender ás suas queixas e de adoptar as medidas permanentes e necessarias para estabelecer o antigo edificio da nossa constituição, deteriorado pelo decurso do tempo; el-rei e os tres estados do reino, clero, nobreza $e$ povo, são as magestosas columnas que o devem sustentar" 25 . No dia 9 de Setembro de 1820, pelos ditos governadores do reino são enviadas as cartas convocatórias para as câmaras municipais, encomendando-lhe que elegessem procuradores "que tenhão as qualidades, e circumstancias, que para tal acto se requerem, os quais virão munidos de Procuração bastante (como sempre foi uso, e costume)", para estarem presentes à abertura das Cortes, em Lisboa, no dia 15 de Novembro de $1820^{26}$.

${ }^{23}$ Cf., O Campeão Portuguez ou o Amigo do Rei e do Povo. V. g., no n. ${ }^{\circ}$ de 16 de Agosto de 1819 , a um dado passo do Memorial dirigido a D. João VI afirma-se, categoricamente, que "não pode haver, Senhor, outro remedio tão poderoso na epocha prezente como a convocação e chamamento regular das Cortes” (p. 124).

24 Quatro documentos do dia 24 de Agosto de 1820, no Porto, invocam a reunião das Cortes: as duas proclamações e o auto de vereação extraordinário terminam com um "vivam as côrtes e por ellas a constituição"; o manifesto aos portugueses da Junta Provisional do Governo Supremo do Reino consagra que, "imitando nossos maiores, convoquemos as côrtes".

25 Documentos para a Historia das Cortes Geraes da Nação Portugueza, op. cit., p. 38.

26 Sobre as polémicas em torno da convocação das Cortes em 1820: Vital MorEIRA e José Domingues, “A primeira polémica politica da Revolução de 1820", in História Jornal de Notícias 13, abril de 2018, pp. 44-53; José Domingues e Vital MoREIRA, "Nas Origens do Constitucionalismo em Portugal: o parecer de J. J. Ferreira Gordo sobre a convocação das Cortes constituintes em 1820", in e-Legal History Review 28, junho de 2018 [Disponivel em:

http://www.iustel.com/v2/revistas/detalle_revista.asp?z=5\&id=15]. (consultado no dia 8 de Julho de 2018). 
A convocatória - semelhante às do período medieval- é silente quanto à forma de eleição a seguir, remetendo para os usos e costumes de sempre. Por isso, na medida do possivel, vamos tentar aproximar-nos desse sistema eleitoral consuetudinário a partir dos escassos subsídios escritos resgatados ao período do parlamentarismo tradicional (1254-1698). A tarefa é temerária e os resultados serão sempre minguados, insatisfatórios e passiveis de infirmação. Desde logo, porque, sendo consuetudinário, o sistema tende a não estar escrito; na verdade, nestes quatro séculos e meio, não se sabe que tenha beneficiado de qualquer diploma normativo geral emitido pelo poder central27; por outro lado, o mais provável é que nem sequer existisse uniformidade e cada concelho seguisse e adaptasse o modo de eleição ao direito local vigente, à sua dimensão e conjunturas próprias de cada época; quanto mais recuamos no tempo mais lacónicas se tornam as fontes escritas; o período cronológico é demasiado alargado, pressupondo mudanças e evoluções dificeis de aferir; e, sobretudo, porque são muito parcos os subsídios documentais que chegaram aos nossos dias, etc...

D. Afonso III reuniu Cortes em Leiria, no ano de 1254, "cum bonis hominibus de conciliis de suo Regni". Esta lacónica afirmação é única e tem sido interpretada como o mais recuado testemunho da presença de representantes do povo português numa assembleia parlamentar ${ }^{28}$. As Cortes de 1261, por seu turno, são consideradas "as primeiras relativamente às quais se possui a certeza de que os procuradores dos concelhos desempenharam um papel, não de simples mensageiros, portadores de súplicas a submeter a despacho régio, mas de membros de uma assembleia que reivindica direitos e que intervém na definição das regras $a$ incluir na lei"29. O mais plausivel é que, ab initio, tenha existido alguma forma de eleição, ainda que muito rudimentar, para se escolherem os representantes concelhios, mas os parlamentos do século XIII são completamente silentes nesta matéria.

Nunca descurando as imensas variantes de pormenor, a documentação dos séculos seguintes permite gizar um procedimento eleitoral iniciado pela carta convocatória, emitida em nome de el-rei ${ }^{30}$, para os concelhos que tinham assento parlamentar (por foral ou privilégio) ${ }^{31}$. Essa carta era lida em vereação, que

27 As nossas sucessivas Ordenações, ao contrário das Ordenanzas Reales de Castilla (Liv. 2, Tít. 11 , Leis 1-2), nem sequer consagram a liberdade eleitoral dos concelhos.

28 Marcello CAETANo, “As Cortes de Leiria de 1254”, in Estudos de História da Administração Pública Portuguesa, organização e prefácio de Diogo Freitas do AMARAL, Coimbra, Coimbra Editora, 1994, p. 36.

29 Marcello CAETANO, "Subsídios para a História das Cortes Medievais Portuguesas", in Estudos de História da Administração Pública Portuguesa, organização e prefácio de Diogo Freitas do AMARAL, Coimbra, Coimbra Editora, 1994, pp. 105-106.

30 Em princípio, porque há Cortes que não foram convocadas pelo rei, v. g., as Cortes de 1385 foram convocadas pelo Mestre de Avis, as Cortes de 1580 foram convocadas pelos governadores e defensores do reino, as Cortes de 1820 (que não chegaram a reunir) foram convocadas pelos governadores do reino.

31 Vide os formulários e cartas convocatórias para os grandes fidalgos e senhores de terra, para os alcaides mores, para as cabeças de comarca e para as outras localidades com assento parlamentar, publicados em Cortes Portuguesas. Reinado de D. Manuel I (Cortes de 1502), edição de João José Alves DiAs, Lisboa, Centro de Estudos Históricos da Universidade Nova de Lisboa, 2001, pp. 19-34; Visconde de SANTARÉm, Alguns Documentos para Servirem de Provas à Parte $1 .^{a}$ das Memorias para a Historia e Theoria das Cortes Geraes que em Portugal se celebrarão pelos tres 
mandava proceder à eleição dos representantes a enviar às Cortes, impondo que se lhe outorgasse procuração com poderes suficientes para tal, feita por tabelião público. Em simultâneo, era eleita uma comissão redactorial para preparar dois documentos -um com os capítulos especiais do concelho e outro com capítulos gerais, a debater com os outros representantes do povo nas Cortes ${ }^{32}$ - sobre os assuntos com dignidade parlamentar ${ }^{33}$.

Quando a carta convocatória chegava ao concelho de destino era convocada - por concelho apregoado- uma assembleia extraordinária ou alargada, diferente das assembleias ordinárias, restritas ou vereações de homens bons. As assembleias alargadas eram "abertas a todos os vizinhos e moradores, ou a vizinhos, ou ainda ao concelho (...) que devia corresponder a grande parte da população masculina, maior e não dependente moradora na cidade, englobando os homens bons, mas significando um grupo muito mais numeroso do que eles'34. Em Loulé, sabemos que, em Dezembro de 1384, reuniu uma assembleia extraordinária para se ler a carta convocatória, enviada pelo Mestre de Avis, para se reunirem as Cortes em Coimbra ${ }^{35}$; idêntica reunião foi convocada para o dia 19 de Abril de 1468, para se ler a convocatória de el-rei D. Afonso V às Cortes de Torres Novas ${ }^{36}$. No Porto, em reunião de 17 de Novembro de 1389 -estando presente o ouvidor de Entre Douro e Minho, Vicente Dinis- foi lida uma carta convocatória, de el-rei D. João I, às Cortes de Évora ${ }^{37}$. Em Braga, no dia 2 de Abril de 1580, pelos oficiais da vereação "foy mandado deitar pregam por esta cidade e arrabaldes e luguares acustumados que todos os cidadãos e povo fosem jumtos nesta camara" para se ler a carta convocatória dos governadores e defensores do reino às Cortes de Almeirim ${ }^{38}$.

A primeira transcrição integral de uma carta convocatória, que nos foi possivel compulsar, data de 10 de Fevereiro 1402. Trata-se da carta enviada por D. João I ao concelho e homens bons da cidade do Porto, rogando e mandando-lhe que escolhessem dois homens bons e entendidos para irem às Cortes de

estados do reino ordenadas no anno de 1824, Lisboa, na Impressão Regia, 1828, pp. 3-4, pp. 1120 e pp. 27-28.

32 Os capítulos gerais são uma inovação introduzida pelas Cortes de Santarém de 1331. A convocatórias régia de 16 de Agosto de 1525, enviada à cidade de Lisboa, já impõe que os procuradores levem "apomtamemtos asy geraes pera as cousas de meu servico e bem do regno como espeçiaees pera o que tocar as cousas da cidade" (Lisboa, AHM - Livro $1 .^{\circ}$ de Cortes, doc. 34).

33 Visconde de SAnTARém, Alguns Documentos para Servirem de Provas à Parte $1 .{ }^{a}$ das Memorias para a Historia e Theoria das Cortes Geraes que em Portugal se celebrárão pelos tres estados do reino ordenadas no anno de 1824, op. cit., p. 80; Francisco Ribeiro da SilVA, "A Participação do Porto nas Cortes de Lisboa de 1619”, op. cit., p. 112.

34 Arnaldo de MELO, "Os mesteirais no governo urbano do Porto nos séculos XIV e XV", in La Gobernanza de la ciudad europea en la Edad Media, J. A. Solorzano Telechea e B. A. Bolumburu (coord.s), Logroño, Centro de Estudios Riojanos, 2011, p. 328.

35 Actas de Vereação de Loulé Séculos XIV-XV, Separa da Revista Al'-Ulyã 7, Loulé, Câmara Municipal, 1999/00, p. 21. Foi deixado espaço em branco para se transcrever a dita carta, mas nunca se chegou a concretizar tal transcrição.

36 Actas de Vereação de Loulé Séculos XIV-XV, op. cit., p. 203.

37 Magalhães BAsto, "Vereações" Anos de 1390-1395, Porto, Câmara Municipal, s/d, p. 42.

38 José MARQues, "Arquivo Municipal: Vereações Municipais de Braga (Janeiro-Maio de 1580)", in Bracara Augusta 57, Braga, Câmara Municipal, 2009-2012, p. 618. 
Montemor-o-Novo: "escolhades antre uos dous homeens boons e entendudos quaes entenderdes que sejam perteençentes pera esta cousa e os Enuyedes aquy uos a monte moor o nouo com uosa procuraçom sofyçyente pera ello"39. Com o tempo, a fórmula dos destinatários foi alargada e melhorada, v. g., a carta convocatória de 31 de Agosto de 1481 já é dirigida aos "Juizes, vereadores, procurador, fidalgos, cavaleiros, escudeiros, homens bons e povo"40. Abaixo veremos que, a partir dos finais do século $\mathrm{XV}$, a convocatória régia também vai incluir os procuradores dos mesteres, entre os que são expressamente convocados para as eleições parlamentares.

Como ficou dito, impunha-se que, no final, o processo eleitoral fosse formalizado por procuração pública outorgada aos representantes eleitos. Nas Cortes de Évora de 1325 surgem as primeiras referências escritas: Martim Anes, procurador do concelho de Soutelo, no dia 9 de Abril desse ano, presta menagem a el-rei habilitado "por huma procuraçom avondosa que pera esto trago" "1; em documento lavrado nas mesmas Cortes, no dia 30 de Abril, refere-se a "procuraçom auondosa qual pera esto conpria" apresentada pelos procuradores da vila de Santarém ${ }^{42}$. Os primeiros exemplares completos desta documentação eleitoral mediévica, que chegaram até à hodiernidade, pertencem às Cortes fernandinas de Leiria de $1376^{43}$, de Torres Novas de $1380^{44}$ e de Santarém de $1383^{45}$. Fernão Lopes faz referência às procurações apresentadas nas Cortes de 1385 pelos procuradores de Lisboa, Évora e todas as outras cidades e vilas do reino ali juntas ${ }^{46}$. Para as Cortes de 1502 são conhecidas várias procurações ${ }^{47}$. E

39 J. A. Pinto Ferreira, "Vereações" Anos de 1401-1449, Porto, Câmara Municipal, 1980, pp. 101-102. Cf. Convocatória de 2 de Julho de 1460: Porto, AHM - Livro $3^{\circ}$ de Vereações, fl. 224; convocatórias de 5 (para o Porto) e 7 (para Évora) de Novembro de 1497: Cortes Portuguesas. Reinado de D. Manuel I (Cortes de 1498), edição de João José Alves DiAs, Lisboa, Centro de Estudos Históricos da Universidade Nova de Lisboa, 2002, pp. 19-22; 22 de Dezembro de 1498 (Cortes Portuguesas. Reinado de D. Manuel I (Cortes de 1499), edição de João José Alves DiAs, Lisboa, Centro de Estudos Históricos da Universidade Nova de Lisboa, 2001, p. 15). Cf. as convocatórias infra referidas, notas de rodapé 56-62.

40 Gabriel PereirA, Documentos Históricos da Cidade de Évora, Segunda Parte, Évora, Tipografia Económica de José d'Oliveira, 1887, pp. 155-156 (edição fac-simile da Imprensa Nacional-Casa da Moeda, 1998). Idênticos destinatários na carta de 5 de Novembro de 1497 dirigida à cidade do Porto (Cortes Portuguesas. Reinado de D. Manuel I (Cortes de 1498), op. cit., pp. 21-22); na carta de 7 de Novembro de 1497 dirigida à cidade de Évora (Cortes Portuguesas. Reinado de D. Manuel I (Cortes de 1498), op. cit., pp. 19-20).

41 Anísio Miguel de Sousa SARAIVA, A Sé de Lamego na Primeira Metade do Século XIV (12961349), Leiria, Magno, 2003, pp. 612-613.

42 Cortes Portuguesas. Reinado de D. Afonso IV (1325-1357), Lisboa, Instituto Nacional de Investigação Científica, 1982, p. 13.

43 A. H. de Oliveira Marques e Nuno José Pizarro Pinto DiAs (eds.), Cortes Portuguesas: Reinado de D. Fernando I (1367-1383), vol. I (1367-1380), Lisboa, Instituto Nacional de Investigação Científica / Centro de Estudos Históricos da Universidade Nova de Lisboa, 1990.

44 A. H. de Oliveira Marques e Nuno José Pizarro Pinto Dias (eds.), Cortes Portuguesas: Reinado de D. Fernando I (1367-1383), vol. I (1367-1380), op. cit..

45 A. H. de Oliveira Marques e João Paulo Salvado (eds.), Cortes Portuguesas: Reinado de D. Fernando I (1367-1383), vol. II (1383), Lisboa: Instituto Nacional de Investigação Científica / Centro de Estudos Históricos da Universidade Nova de Lisboa, 1993.

46 Fernão Lopes, Crónica de D. João I, Parte I, cap. 181.

47 Cortes Portuguesas. Reinado de D. Manuel I (Cortes de 1502), op. cit., pp. 37-81. 
assim sucessivamente, para Cortes posteriores ${ }^{48}$. A redacção da procuração, por parte de um tabelião público, pressupunha uma aprovação prévia em assembleia alargada da vereação ${ }^{49}$. A procuração escrita é característica do chamado mandato imperativo, definindo e limitando os poderes de actuação dos representantes ${ }^{50}$. Este documento, como parte integrante do procedimento eleitoral, vai-se repercutir até à última reunião de Cortes, nos finais do século XVII, e é explicitamente exigido na carta convocatória de 9 de Setembro de $1820^{51}$.

A cúspide do procedimento eleitoral, situada algures entre a convocatória e a procuração, corresponde à eleição efectiva dos procuradores do povo ou procuradores concelhios. Como não podia deixar de ser, este acto era feito em assembleia extraordinária, com a concorrência dos ministros da vereação, da fidalguia local, dos homens bons e da maior parte do povo ${ }^{52}$. A tónica popular destas eleições vai acentuar-se consideravelmente, a partir dos finais do século XIV e século XV, com o ingresso dos procuradores dos mesteres no seio das vereações municipais ${ }^{53}$. Os mesteirais da Casa dos Vinte e Quatro passam a ser

48 Cf. Lisboa, AHM - Livro 2. ${ }^{\circ}$ de Cortes, doc. 4 (procuração, de 15 de Dezembro de 1579, a Febo Moniz e Manuel de Sousa Pacheco), doc. 5 (segunda procuração, de 10 de Fevereiro de 1580 , a Febo Moniz e Manuel de Sousa Pacheco), doc. 12 (procuração, de 13 de Fevereiro de 1581, a Rodrigo de Menezes e Damião de Aguiar), doc. 25-B (procuração, de 11 de Julho de 1619, a Jerónimo Coutinho e Nuno da Fonseca); Visconde de SANTARÉm, Alguns Documentos para Servirem de Provas à Parte 1. ${ }^{a}$ das Memorias para a Historia e Theoria das Cortes Geraes que em Portugal se celebrárão pelos tres estados do reino ordenadas no anno de 1824, op. cit., pp. 9-11 e pp. 20-26.

49 Em Loulé, no dia 27 de Fevereiro de 1385, reuniu a vereação "e a moor parte de todolos pobres da dicta vila" para acordarem a outorga de procuração a Diogo Anes e Estêvão Anes, bem como um valor monetário para as suas despesas (Actas de Vereação de Loulé Séculos XIV-XV, op. cit., p. 37).

50 É comummente aceite que não existe mandato representativo até aos finais do século XIX. Não devemos deixar de ter em conta, no entanto, que desde as Cortes de 1331 os procuradores do povo podiam discutir e formular capítulos gerais no interesse comum e boa governabilidade do reino. Na Idade Média a "regra geral foi a de os procuradores serem representantes e não meros porta-vozes. E isso desde muito cedo. Sem dúvida desde 1331" (Armindo de SousA, "Estado e Comunidade: Representação e Resistência”, in O Parlamento Medieval Português e Outros Estudos, Porto, Fio da História, 2014, p. 307).

51 Collecção de Leis, Decretos, e Alvarás, Ordens Regias, e Editaes, que se publicarão desde o Anno de 1817 até 1820, Lisboa, na Impressão Régia, 1820.

52 Em Loulé, em Fevereiro de 1385, reuniu a vereação e dois tabeliães com "outros muitos homens boons da dicta vila e a maior parte dos pobres" para elegerem os seus procuradores a enviar às Cortes e Coimbra (Actas de Vereação de Loulé Séculos XIV-XV, op. cit., pp. 35-36); no Porto, à assembleia eleitoral de 24 de Novembro de 1497, estiveram presentes trinta e quatro pessoas identificadas e outros muitos do povo que não são nomeados por o escrivão lhes não saber o nome (Cortes Portuguesas. Reinado de D. Manuel I (Cortes de 1498), op. cit., pp. 25-27).

53 Bruno Marconi da COSTA, "Os mesteirais e o concelho de Lisboa no século XIV: um esboço de sintese (1300-1383)", in Medievalista 21, 2017, pp. 1-29 [Disponivel em: http://www2.fcsh.unl.pt/iem/medievalista/MEDIEVALISTA21/costa2105.html (consultado no dia 3 de Abril de 2017)]; Arnaldo de MELO, "Os mesteirais e o poder concelhio nas cidades medievais portuguesas (séculos XIV e XV)", in Edad Media. Revista de Historia 14, 2013, pp. 149170; Arnaldo de MELO, "Os mesteirais no governo urbano do Porto nos séculos XIV e XV", in La Gobernanza de la ciudad europea en la Edad Media, J. A. Solorzano Telechea e B. A. Bolumburu (coord.s), Logroño, Centro de Estudios Riojanos, 2011, pp. 323-347; Mário FARELO, A Oligarquia Camarária de Lisboa (1325-1433), Faculdade de Letras da Universidade de Lisboa, 2008, pp. 6773 (tese de doutoramento) [Disponivel em: http:/ / hdl.handle.net/10451/569 (consultado no dia 3 de Abril de 2017)]; José Viriato CAPELA, "Os Mesteres na Câmara e Governo Concelhio Bracarense 
membros activos nessas assembleias eleitorais. De salientar que não se ficaram pela capacidade eleitoral activa e, para além de integrarem o corpo eleitoral do municipio, em determinados momentos tiveram participação directa em Cortes ${ }^{54}$. Desde o reinado de D. Duarte, pelo menos, que os "procuradores do povo miúdo" apresentam "delegações paralelas", em contrapeso às delegações dos outros "procuradores do povo", que, em princípio, estariam condicionados pelos interesses do poder oligárquico municipal ${ }^{55}$.

A Partir dos finais do século XV, a sua intervenção no procedimento eleitoral dos procuradores dos concelhos passa a estar assegurado pela própria convocatória régia. A carta de 22 de Dezembro de 1498 já inclui o(s) procurador(es) dos mesteres, a seguir aos outros oficiais do poder concelhio: "[juizes], Vereadores, procurador e procurador dos mesteres fidalgos e caualeiros escudeiros homeens boons e pouo"56. As sucessivas convocatórias dirigidas à cidade de Lisboa vão manter a prerrogativa $-v$. g., convocatórias de 16 de Agosto de $1525^{57}, 4$ de Janeiro de $1581^{58}$, de 26 de Março de 164959, de 12 de Abril de $1619^{60}$, de 2 de Novembro de 163361, de 7 de Outubro de $1673^{62}$ - até à convocatória, supra referida, de 9 de Setembro de 1820.

Muito embora a convocatória régia seja dirigida aos procuradores dos mesteres, um privilégio ancestral assegurava direito de voto a todos os Vinte e

durante o Antigo Regime (e em torno de um processo de subalternização politica das classes mecânicas)", in Cadernos do Noroeste (Séries História) 15 (1-2), 2001, pp. 219-248.

54 Portugal não é um caso isolado. "The representation of the commons was originally not a feature of Old European parliaments. However, by at the latest 1500 their representation had become cus-tomary". Cf. Peter BLICKLE, "Representing the 'common man' in old European parliaments", in Actes del 53è Congrés de la Comissió Internacional per a l'Estudi de la Història de les Institucions Representatives i Parlamentàries I, J. Sobrequés, J. Agirreazkuenaga, M. Morales, M. Urquijo i M. Cisneros (coords.), Barcelona, 2005, pp. 117-132 (121).

55 Maria Ângela BeIRANTE, Ao Serviço da República e do Bem Comum: Os vinte e quatro dos mesteres de Évora, paradigma dos vinte e quatro da Covilhã (1535), Lisboa, Centro de Estudos Históricos, 2014, pp. 82-92; Arnaldo de MELO, "Os mesteirais e o poder concelhio nas cidades medievais portuguesas (séculos XIV e XV)”, op. cit., 2013, pp. 161-162; Armindo de SousA, As Cortes Medievais Portuguesas (1385-1490), Porto, Instituto Nacional de Investigação Científica, 1990, pp. 210-214. Uma carta de D. Manuel I, de 10 de Março de 1498, reformula um dos capítulos de que o "procurador do povo miúdo" de Elvas se agravara nas Cortes de Lisboa (Cortes Portuguesas: Reinado de D. D. Manuel I (Cortes de 1498), op. cit., pp. 567-568).

56 Cortes Portuguesas. Reinado de D. Manuel I (Cortes de 1499),op. cit., p. 15.

57 Lisboa, AHM - Livro $1 .^{\circ}$ de Cortes, doc. 34.

58 Visconde de SANTARÉm, Alguns Documentos para Servirem de Provas à Parte $1 .^{a}$ das Memorias para a Historia e Theoria das Cortes Geraes que em Portugal se celebrárão pelos tres estados do reino ordenadas no anno de 1824, op. cit., pp. 3-4.

59 Visconde de SANTARÉm, Alguns Documentos para Servirem de Provas à Parte $1 .{ }^{a}$ das Memorias para a Historia e Theoria das Cortes Geraes que em Portugal se celebrárão pelos tres estados do reino ordenadas no anno de 1824, op. cit., pp. 11-12.

60 Lisboa, AHM - Livro 2. ${ }^{\circ}$ de Cortes, doc. 23, fl. 81.

61 Lisboa, AHM - Livro 2. ${ }^{\circ}$ de Cortes, doc. 27, fl. 110.

62 Lisboa, AHM - Chancelaria régia, Livro 2. ${ }^{\circ}$ de Consultas e de Decretos de D. Pedro II, fls. 320-321v. 
Quatro -ou mesmo aos Quarenta e Oito63_ e não apenas aos representantes com assento na vereação ${ }^{64}$. Em 1634 os quatro representantes dos mesteres na câmara de Lisboa recusam-se a votar e a tomar assento sobre a eleição dos procuradores às Cortes, requerida por carta de el-rei de 2 de Novembro de 1633, sem consentimento e voto de todos os vinte e quatro e de todo o reino. D. Filipe III pretendia que reunissem Cortes em Lisboa apenas com a presença de cinco representantes do braço eclesiástico, cinco do braço da nobreza e dez do braço do povo65 -eleitos pelas quatro cidades (Porto, Évora, Lisboa e Coimbra) e vila (Santarém) do primeiro banco, dando as câmaras das outras cidades e vilas do reino (que tivessem voto em Cortes), poder e procuração bastante às do primeiro banco e respectivos procuradores eleitos-66. O juiz e os vinte e quatro procuradores do povo, em determinado passo, alegam que a eleição dos procuradores para Cortes se não faz, nem pode fazer, só com os votos da câmara desta cidade e dos procuradores dos mesteres, senão com votos de todos os vinte $e$ quatro e das mais pessoas que costumam ser chamadas ${ }^{67}$.

O colégio eleitoral dos mesteirais acaba por reflectir a preocupação de alargar e democratizar o processo eleitoral. Mas é óbvio que esta representação politica corporativa só é possível nas cidades e vilas em que existe a organização autocéfala da Casa dos Vinte e Quatro. Em suma, o rei convocava a eleições as pessoas da governança, os procuradores dos mesteres, os fidalgos, cavaleiros e escudeiros, os restantes homens bons e todo o povo. Todo o procedimento destila a preocupação com uma adequada e alargada representação política da comunidade. $\mathrm{Na}$ realidade, chegam a ser convocados estamentos e pessoas que, não raro, estavam impedidos de assistir e estar presentes às sessões ordinárias da vereação.

${ }^{63}$ Francisco Ribeiro da Silva, "A Participação do Porto nas Cortes de Lisboa de 1619”, op. cit., p. 109 , nota 18 .

64 Os vinte e quatro procuradores do povo estiveram presentes à eleição dos procuradores de Lisboa a enviar às Cortes, no dia 12 de Fevereiro de 1579 (Lisboa, AHM - Livro 2. ${ }^{\circ}$ de Cortes, doc. 1), no dia 19 de Novembro de 1579 (Lisboa, AHM - Livro 2. ${ }^{\circ}$ de Cortes, doc. 2), no dia 20 de Junho de 1580 (Lisboa, AHM - Livro 2. ${ }^{\circ}$ de Cortes, doc. 6), no dia 7 de Janeiro de 1583 (Lisboa, AHM Livro $2 .^{\circ}$ de Cortes, doc. 21) e no dia 4 de Julho de 1619 (Lisboa, AHM - Livro $2 .^{\circ}$ de Cortes, doc. 25).

65 A tentativa de implementar Cortes mais restritas, com representantes eleitos pelas comarcas, recua ao regimento do reino aprovado nas Cortes de Torres Novas, em Novembro de 1438 (cf. Cortes Portuguesas: Reinado de D. Afonso V (Cortes de 1438), organização e revisão geral de João José Alves Dias e Pedro PinTo, Lisboa, Centro de Estudos Históricos Universidade Nova, 2014, pp. 39-64); às Cortes de Coimbra de 1472 ( $c f$. o documento publicado por Pedro PINTO, "Documentação avulsa medieval e moderna do Arquivo Histórico Municipal de Santarém primeira parte (D. Afonso III a D. João III)", in Mátria Digital 2, 2014/2015, p. 17); e às Cortes de 1502 (cf. Cortes Portuguesas. Reinado de D. Manuel I (Cortes de 1502), op. cit.). Cf. Armindo de SousA, "As Cortes Portuguesas nos Reinados de D. João II e de D. Manuel I", in O Parlamento Medieval Português e Outros Estudos, Porto, Fio da História, 2014, pp. 327-328.

${ }^{66}$ Lisboa, AHM - Livro 2..$^{\circ}$ de Cortes, doc. 28 N. Cf. Visconde de SAnTARÉm, Memorias para a Historia e Theoria das Cortes Geraes que em Portugal se celebrarão pelos tres estados do reino ordenadas e compostas neste anno de 1824, Parte I, op. cit., p. 5.

67 Lisboa, AHM - Livro 2. ${ }^{\circ}$ de Cortes, doc. 28 A-Q. As eleições de 8 de Abril de 1634 foram muito pouco participadas (29 votantes), acabaram por ser impugnadas e as Cortes foram desconvocadas. 
Um caso sintomático para a democracia eleitoral medieva ocorreu no início do ano de 1498, em Torre de Moncorvo, por causa dos procuradores eleitos às Cortes desse ano. Os titulares da vereação e regimento da vila elegeram o representante e a comissão redactorial dos apontamentos a enviar às Cortes em assembleia ordinária, sem terem convocado o povo a eleições. Tal procedimento estava desconforme com o que era imposto pela missiva convocatória de el-rei. A pedido de quatro procuradores eleitos pelo povo foi redigido pelo tabelião, perante o vereador João esteves, um instrumento para de tal acto se apresentar queixa junto do monarca. O povo queixa-se contra a elite formada em torno do alcaide mor, Fernão Vasques de Sampaio, que controlava as rédeas do poder local e tinha eleito o procurador de Cortes. O dito vereador presente à acusação, João Esteves, respondeu por escrito, concordando e corroborando o fundamento da queixa popular. Em nome do juiz e oficiais da câmara foi contestada -também por documento escrito, lavrado por um dos visados e membro da vereação, Pero Anes- a queixa dos populares, admitindo ser verdade que tinham escolhido o procurador a enviar às Cortes sem convocar o povo, mas que tal the era permitido por costume antigo.

Os argumentos aduzidos por Pero Anes consubstanciam a neoplasia de qualquer democracia representativa: a escolha dos melhores para a representação política ${ }^{68}$. Para a elite oligárquica de Moncorvo, no ocaso da Idade Média, os lavradores são consideradas pessoas ignorantes e que sabiam mais de suas lavouras do que dos feitos de el-rei e das Cortes - "os llauradores Estes ssóm pouco ssaybaãos e ssaybem mays de ssuas llanças que dos ffeytos $d$ ell Rey nem de ssuas cortees"-; de forma que os membros da câmara desde antigamente têm por costume meter os melhores do lugar no regimento da vila, por saberem dar conta e recado do que lhes competia, ao contrário dos lavradores, que dariam má conta de tais encargos - "assy que $d$ antyguamente tem por custume meterem os melhores do llugar no rregymento da ujlla e assy nos offycjaes e caregos $d$ ell Rey $e$ do conçeelho por ssabeerem dar conta e rrecado do que lhe emcarregõm e ssaberem sserujr a ssua alteza mjlhor que elles llauradores que queryam que os emcarregassem do que daryam maa conta"-.

Este instrumento lavrado pelo tabelião público de Moncorvo seguiu para as Cortes, junto com um pedido feito pelo procurador do povo miúdo, João Esteves. Solicitam a el-rei justiça para o caso e pedem que se faça nova eleição, com acordo do povo e termo da dita vila, para que na vereação passe a haver "tantos por tantos", i. e., que, com o acordo de todos, se ponham no regimento da vila tantos homens da terra como da vila, de maneira que os da vila não possam decidir sem os da terra, tal como se fazia em outras vilas e lugares dessa comarca, v. g., Castelo Rodrigo69.

Os primeiros autos de eleição conhecidos são demasiado parcos em detalhes sobre o procedimento eleitoral que era seguido. Não raro, limitam-se a identificar os nomes dos representantes escolhidos. As expressões registadas pretendem

68 Por isso é que, séculos mais tarde, Alexandre Herculano asseverava que "o direito eleitoral é uma espada de dois gumes com que os cidadãos estão armados para se defenderem a si e a seus filhos, mas com que também podem assassinar-se e assassiná-los": Alexandre HERCULANO - "Carta aos Eleitores do Círculo de Sintra em 1858", in Opúsculos II, Lisboa, em Casa da Viúva Bertrand e C. ${ }^{a}, 1873$, p. 229.

69 Cortes Portuguesas. Reinado de D. Manuel I (Cortes de 1498), op. cit., pp. 33-40. 
inculcar uma certa unanimidade (que muito raro e dificilmente teria existido ${ }^{70}$ ), $v$. g., em 1389 "e todos diserom que Era bem e escolherom logo pera hir aas ditas Cortes"71, em 1402 "Acordarom que os ffezessem procuradores"72, em 1476 "acordarom todos e enllegerom por procurador"

Antes de mais, ter-se-á em conta que não estamos perante um modelo eleitoral petrificado, uniforme em todos os tempos e para todos os sítios ${ }^{74}$. Nuno Resende, $v$. g., no dia 14 de Junho de 1460, foi eleito procurador portuense "per pelouro"75. Foi o único caso que, até à data, nos surgiu de uma eleição feita por pelouros. O mais plausivel é que se tenha adaptado às eleições parlamentares gerais a legislação eleitoral vigente para os cargos locais (juízes, vereadores, procuradores, coudéis, escrivães da câmara, juízes e escrivães dos órfãos). Tratase da célebre ordenação dos pelouros, da lavra de D. João I, de 12 de Junho de 1391, desenvolvida pelo regimento dos corregedores de 12 de Setembro de 1418 e compilada na Reforma das Ordenações de D. Afonso V de 144676 . Tendo por base o preceituado nessa primordial lei eleitoral, o mais plausível é que, na eleição portuense de 1460: (i) se tenha constituído um colégio eleitoral de homens bons (os elegedores) para escolherem os candidatos a representantes nas Cortes; (ii) a lista prévia dos candidatos tenha sido apresentada para ratificação em assembleia alargada; (iii) se tenha feito um pelouro para cada candidato, de seguida, metidos num saco de pano; (iv) perante todos os presentes, um moço de sete anos terá metido a mão no saco e, revolvendo bem os pelouros, terá tirado um; (v) dentro desse pelouro estaria escrito o nome de Nuno Resende ${ }^{77}$.

Os primeiros indícios escritos, para o que poderá ser considerado como o procedimento mais corrente ${ }^{78}$, surgem nas eleições feitas no Porto, no dia 24 de

\footnotetext{
70 Antes pelo contrário, há provas documentais de eleições que foram contestadas. Como, v. g., as referidas eleições de Moncorvo de 1498 e as eleições de Barcelos de 1642 (Visconde de SANTARÉm, Alguns Documentos para Servirem de Provas à Parte $1 .^{a}$ das Memorias para a Historia e Theoria das Cortes Geraes que em Portugal se celebrárão pelos tres estados do reino ordenadas no anno de 1824, op. cit., pp. 29-41).
}

71 Magalhães BAsto, "Vereações" Anos de 1390-1395, op. cit., p. 43.

72 J. A. Pinto Ferreira, "Vereações" Anos de 1401-1449, op. cit., p. 103.

73 Porto, AHM - Livro 4 de Vereações (A-PUB 0005), fls. 35v-38v.

74 O próprio monarca, por carta de 9 de Agosto de 1502, dispensou a realização de eleições em Lisboa e determinou que os seus representantes nas Cortes de juramento do príncipe D. João fossem os vereadores em exercício de funções ( $C f$. Cortes Portuguesas. Reinado de D. Manuel I (Cortes de 1502), op. cit., pp. 35-36).

75 Porto, AHM - Livro $3^{\circ}$ de Vereações, fls. 223v-224.

76 Ordenaçoens de El-Rey D. Affonso V, Coimbra, Real Imprensa da Universidade, 1792 (facsimile da Fundação Calouste Gulbenkian, 1984/1998), Livro I, Título 23, pp. 135-138. Sobre eleição por pelouros, $c f$. José Viriato CAPELA, "Eleições e Sistemas Eleitorais nos Municípios Portugueses de Antigo Regime", in Eleições e Sistemas Eleitorais: Perspectivas Históricas e Politicas, Maria Antonieta CRUZ (org.), Porto, Universidade do Porto Editorial, 2009, pp. 21-83; Luís Miguel DUARTE, "Eleições municipais no Algarve no início do século XV", in Actas das I Jornadas de História Medieval do Algarve e Andaluzia (Loulé 23 a 25 de Novembro de 1984), Loulé, 1987, pp. 297-304.

77 Porém, nada obsta a que, em vez de novos pelouros, tenham aproveitado os pelouros que estavam guardados na arca do concelho.

78 Cf. a descrição do processo eleitoral seiscentista, no Porto, por Francisco Ribeiro da SILVA, "Os Concelhos e as Cortes Seiscentistas portuguesas: representação e intervenção (o caso do 
Novembro de 1497. Após a leitura da carta convocatória, o procurador da cidade deu juramento dos Santos Evangelhos a todos os presentes para que, bem e verdadeiramente, cada um nomeasse dois bons homens para irem às Cortes. Depois de todos jurarem, o escrivão da câmara tomou uma folha de papel onde escreveu e apontou o voto oral (vozes) de cada um, saindo mais votados os cidadãos Vasco Carneiro e Afonso Tomé79. As vozes ou votos orais são registados pelo escrivão da câmara: os votantes ajuramentados, um de cada vez, aproximava-se da mesa de voto e manifestava a sua intenção de voto; o escrivão registava os nomes indicados e colocava um pequeno traço vertical à frente; se a pessoa indicada já constasse da lista, por ter sido escolhida por um eleitor anterior, o escrivão limitava-se a acrescentar novo traço à frente do nome proferido $^{80}$.

Em Lisboa, a actividade de escrutínio do escrivão era controlado pelo corregedor ou conservador da cidade $-v$. g., nas duas eleições realizadas no ano de 157981 , na de $1580^{82}$, na de $1583^{83}$, na de $1619^{84}$ e na de $1697^{85}$ - e no Porto pelo juiz de fora. Depois de o último eleitor ter votado, contavam-se os riscos à frente de cada nome e consideravam-se eleitos os mais votados. Em caso de empate, considerava-se eleito o individuo referido em primeiro lugar na lista ${ }^{86}$.

No dia 2 de Fevereiro de 1698 foi feito um assento pormenorizado sobre o procedimento eleitoral seguido, em Lisboa (igreja de Santo António), no dia 17 de Outubro de 1697. Os fidalgos e desembargadores tinham sido convocados por carta escrita e os cidadãos por róis. Foram armadas duas mesas: a mesa do senado (junto às colunas do coro) e a mesa do escrutínio (no cruzeiro da igreja), ocupada pelo escrivão e pelo conservador da cidade para assentar os votos de cada um dos votantes. O assento dá conta da disposição onde ficaram sentados os oficiais do senado municipal, os procuradores da cidade, os procuradores dos mesteres, o juiz do povo e o seu escrivão, os membros da Casa dos Vinte e Quatro, os fidalgos, os desembargadores e os cidadãos. A ordem de votação foi a seguinte: vogais presentes, procuradores dos mesteres, juiz do povo e seu escrivão, Casa dos Vinte e Quatro e aquelas pessoas que nela tinham sido juízes

Porto)", op. cit., pp. 66-68; Francisco Ribeiro da SilvA, "A Participação do Porto nas Cortes de Lisboa de 1619", op. cit., p. 110-111.

79 Cortes Portuguesas. Reinado de D. Manuel I (Cortes de 1498), op. cit., pp. 25-27.

80 Chegaram até aos nossos dias listas de eleições da cidade de Lisboa de 12 de Fevereiro de 1579 (Lisboa, AHM - Livro 2. ${ }^{\circ}$ de Cortes, doc. 1-C), de 19 de Novembro de 1579 (Lisboa, AHM Livro 2. ${ }^{\circ}$ de Cortes, doc. 2), de 20 de Junho de 1580 (Lisboa, AHM - Livro 2. ${ }^{\circ}$ de Cortes, doc. 6), de 1581 (Lisboa, AHM - Livro 2. ${ }^{\circ}$ de Cortes, doc. 7), de 1 de Fevereiro de 1581 (Lisboa, AHM - Livro $2 .^{\circ}$ de Cortes, doc. 9), de 7 de Janeiro de 1583 (Lisboa, AHM - Livro 2. ${ }^{\circ}$ de Cortes, doc. 22) e de 4 de Julho de 1619 (Lisboa, AHM - Livro 2. ${ }^{\circ}$ de Cortes, doc. 25); da vila de Santarém de 5 de Outubro de 1679 (Martinho Vicente Rodrigues, A Vila de Santarém (1640-1706): Instituições e Administração Local, Câmara Municipal de Santarém, 2004, p. 413).

81 Lisboa, AHM - Livro 2. ${ }^{\circ}$ de Cortes, doc. 1 e doc. 2.

${ }^{82}$ Lisboa, AHM - Livro 2. ${ }^{\circ}$ de Cortes, doc. 6.

83 Lisboa, AHM - Livro 2. ${ }^{\circ}$ de Cortes, doc. 21.

84 Lisboa, AHM - Livro 2. ${ }^{\circ}$ de Cortes, doc. 25.

85 Eduardo Freire de OliveIRA, Elementos para a Historia do Municipio de Lisboa, $1 .{ }^{a}$ Parte, Tomo I, Lisboa, Tipografia Universal, 1885, pp. 112-113.

86 Porto, AHM - Livro de Vereações 50, fl. 130. 
do povo, seus escrivães e procuradores dos mesteres. Por fim, o escrivão da câmara e o conservador da cidade vieram à mesa do senado tomar votos ao presidente e ministros do senado lisboeta, que votaram por suas precedências. Terminada a eleição, o escrivão e conservador voltaram para o seu lugar e fizeram a contagem dos votos e pediram licença ao presidente do senado para publicar a eleição. Publicada a eleição dos dois nomes mais votados, a pauta foi entregue ao presidente do senado para a apresentar a el-rei. Dali a alguns dias, os eleitos prestaram juramento e foi-lhes outorgada a respectiva procuração ${ }^{87}$.

De salientar a celeridade do processo, uma vez que, não raro, tudo era feito em sessão do mesmo dia: leitura da convocatória régia, eleição dos representantes, escolha da comissão redactorial e mandato para se lhe outorgar procuração na forma costumada. A celeridade do processo era tida como uma forma eficaz de combate à eventual corrupção eleitoral. Nem sequer se dava azo à elaboração de uma lista prévia de candidatos, que eram sucessivamente designados pelos próprios votantes, no decurso do acto eleitoral. O sufrágio era oral, mas não era público. Apesar de não obedecer aos moldes do sufrágio secreto hodierno, pode dizer-se que tinha um acentuado cariz secreto, uma vez que era individual, a mesa de escrutínio estava isolada (para não se ouvirem as declarações de voto) e o escrivão e o magistrado fiscalizador estavam obrigados ao sigilo.

Quanto à representação política, tudo indica que "o colégio eleitoral tinha uma componente genuinamente popular ainda que situada nos estratos superiores do povo. Mas os eleitos são sempre fidalgos ou cidadãos recrutados na melhor aristocracia local's8.

A missiva convocatória já impõe certas características para se ser representante do povo em Cortes, v. g., deviam ser pessoas discretas, honradas, de bom viver, inclinadas ao bem comum e sem nenhuma afeição (imparciais, sobretudo, em relação ao poder local) ${ }^{89}$. Os procuradores deviam ser suficientemente competentes para tal feito. D. João III, na convocatória de 16 de Agosto de 1525, enviada à cidade de Lisboa, teve o cuidado de particularizar que elegessem pessoas "de tall boomdade saber e discriçam e como pera tall auto se requerem e que sejam asy sofiçiemtes e saibam e tenham pratica das cousas do regno que acerqua dellas e de todo o mais que nas ditas cortes se fallar tratar $e$ praticar saibam dar tall rezam como comvyer a milhor asemto e beem de todas as cousas"90. Por costume, Lisboa elegia um procurador fidalgo e outro letrado, não raro, angariado no seio da Casa do Cível ${ }^{91}$. Em 1460, na cidade do Porto, foi decidido que Gabriel Barreiros acompanhasse o procurador eleito, Nuno Resende, por aquele ser pessoa experiente de outras Cortes passadas ${ }^{92}$. Mediante a recusa

87 Eduardo Freire de OlIVEIRA, Elementos para a Historia do Municipio de Lisboa, op. cit., pp. 112-115.

88 Francisco Ribeiro da Silva, O Porto e o seu Termo 1580-1640: Os homens, as instituições e o poder, vol. I, Porto, 1985, p. 263 (Tese de Doutoramento).

89 Convocatória de 5 de Novembro de 1497, à cidade do Porto, em Cortes Portuguesas. Reinado de D. Manuel I (Cortes de 1498), op. cit., pp. 21-22.

90 Lisboa, AHM - Livro $1 .^{\circ}$ de Cortes, doc. 34.

91 Lisboa, AHM - Livro 1. ${ }^{\circ}$ de Cortes, doc. 35.

92 Porto, AHM - Livro $3^{\circ}$ de Vereações, fls. 224v-225. 
fundamentada de Gabriel Barreiros, a vereação portuense decidiu constituir um colégio de consulta, composto por aqueles que tivessem melhor conhecimento e experiência de outras Cortes ${ }^{93}$.

A nivel de incapacidade eleitoral passiva, em 13 de Novembro de 1579, impede-se que sejam candidatos os oficiais régios ${ }^{94}$ e, em 3 de Julho de 1674, o impedimento é dirigido aos julgadores, oficiais de guerra e soldados ${ }^{95}$.

Retomando o fio à meada, ficou dito que os três estados do reino foram convocados pelo Governo de Lisboa para as Cortes constituintes, a reunir em meados de Novembro de 1820. Mas essa convocatória não se concretizou porque, no dia 15 de setembro, o Governo de Lisboa foi substituído por um Governo interino, alinhada com os ideais dos revolucionários do Porto. No dia 27 de setembro de 1820, em Alcobaça, fundiram-se os dois executivos (do Porto e Lisboa) e formou-se uma única Junta Provisional do Governo Supremo do Reino para todo o País. Para se unir com o Governo interino de Lisboa, a Junta governativa do Porto entrou triunfante em Lisboa no dia 1 de outubro desse ano.

Em simultâneo foi criada a Junta Provisional Preparatória das Cortes que, por portaria de 6 de Outubro desse ano, entendeu ouvir a opinião pública mais ilustrada sobre o melhor e mais eficaz método de representação em Cortes. Para tal, determinou que se consultassem, "não só, as corporações scientificas e os homens conhecidos pela sua profissão litteraria, mas tambem, acolher com toda a cordialidade quaesquer trabalhos que forem dirigidos pelas pessoas a quem a sua modestia impede de figurarem com ostentação scientifica" ${ }^{\text {". }}$. Concomitantemente, convocou os grandes e titulares do reino. Sem surpresa, tudo parece indicar que a maioria dos convocados "tinham votado a favor da fórma antiga, isto é, que se fizesse o acto convocatorio pelos tres estados do reino"97.

Uma das primeiras manifestações em contrário terá caído da pena de Manuel Borges Carneiro. Apesar de, aparentemente, estar ligado à convocação das Cortes nos moldes tradicionais, o Adicionamento do Desembargador do Porto, de 13 de Outubro de 1820, revela uma crítica mordaz contra a convocação tradicional das Cortes ${ }^{98}$. Nesse Adicionamento, que foi acrescentado à $2 .^{a}$ edição do Portugal Regenerado, o autor questiona-se se "a fórma de convocar as Cortes $e$ de proceder a todo o este respeito, que até o anno de 1698 se praticou em Portugal,

93 Porto, AHM - Livro $3^{\circ}$ de Vereações, fls. 225v-226.

94 Lisboa, AHM - Livro $1 .^{\circ}$ de Cortes, doc. 40.

95 José Justino de Andrade e Silva, Collecção Chronologica da Legislação Portugueza Compilada e Annotada, Lisboa, Imprensa de F. X. de Souza, 1857, p. 316.

96 Defendendo uma convocatória tardicional dos três "estados" do reino a Cortes, com variantes de adaptação ao século XIX, são conhecidos o excerto do parecer da Academia Real das Ciências de Lisboa, elaborado por uma equipa que foi liderada por Trigoso de Aragão Morato, e o parecer de José Joaquim Ferreira Gordo. $C f$. José Domingues e Vital MoREIRA, "Nas Origens do Constitucionalismo em Portugal: o parecer de J. J. Ferreira Gordo sobre a convocação das Cortes constituintes em 1820", in e-Legal History Review 28, junho de 2018.

97 Documentos para a Historia das Cortes Geraes da Nação Portugueza, op. cit., p. 78.

98 Zília Osório de CASTRo, Cultura e Politica. Manuel Borges Carneiro e o Vintismo, vol. I, Lisboa, Instituto Nacional de Investigação Científica e Centro de História da Cultura da Universidade Nova de Lisboa, 1990, pp. 55-57 [Disponivel em: http://hdl.handle.net/10362/3994 (consultado no dia 25 de Abril de 2017)]. 
póde convir ao tempo presente?". A que responde terminantemente: "de nenhuma maneira" ${ }^{\prime 99}$. Nesse ano de 1820 ainda foram publicados dois pareceres, no mesmo sentido, apresentados ao Governo Supremo do Reino: o parecer de José Teotónio Canuto de Forjó, de 24 de Outubro, que aconselha "eleições com todas aquellas formalidades, que judiciosamente adoptou a Constituição de Hespanha"100; e o parecer de Francisco José de Almeida, de 25 de Outubro, que instiga a uma "Representação decorosa e legitima em Côrtes, Côrtes à Hespanholla, de que todo o Mundo faz huma clara idéa, e não esse carcomido e exangue esqueleto sobrecarregado de vaidosos atavios, que nem assim cobre suas pulverulentas ruinas ha tão longos annos sotterrado"; entendendo que a "Constituição de Hespanha de 1812 offerece hum modelo (em meu juizo) que não póde exceder-se na maneira gradual por que a eleição vai subindo des dos Eleitores Parroquiaes até áquella dos Deputados às Côrtes"101. "Os jornaes liberaes -assevera José de Arriaga- protestam todos egualmente contra as velhas côrtes, como imcompativeis com as luzes do seculo e os modernos interesses do Estado"102.

Entretanto, vai formalizar-se a contestação do juiz do povo e casa dos vinte e quatro de Lisboa. No dia 25 de Outubro, esta corporação deliberou que "os membros para representarem em côrtes fossem escolhidos indistinctamente da massa geral da nação, seguindo-se para se obter este fim a mesma fórma determinada na digna constituição hespanhola (...) devendo ser desprezada toda a idea de uma convocação de côrtes da maneira antigamente practicada, do que só resultaria a inutilidade das honrosas fadigas gloriosamente soffridas para se conseguir uma livre constituição adaptada às puras ideas do tempo e às nossas necessidades"103. De seguida, comunicaram a resolução ao exército, que aderiu de imediato, e também não demorou a surgir o manifesto condizente da Junta Provisional do Governo Supremo do Reino.

Efectivamente, no dia 31 de Outubro de 1820, o governo manifesta-se veementemente contra as Cortes tradicionais, assegurando que a revolução não tinha sido feita "para resuscitar as antiquadas fórmas do feudalismo e o vão simulacro de côrtes". A exortação final do manifesto soa a um grito de nova revolta, a "revolta eleitoral" de 1820:

\footnotetext{
"Portuguezes! Vigilancia, cautela, circumspecção! Não esmigalhámos os ferros para nos vendermos servis aos partidos e às facções. Profanam-se as santas mãos da liberdade, quando depositam seus votos n'outra urna que não seja o seio da patria. Considerae, $e$ considerae desde já, e considerae até ao derradeiro momento das eleições, que ides commetter vossos bens, vossas liberdades, vossas pessoas, e todas as relações que vos são mais caras até a ultima posteridade, nas mãos de vossos deputados. Serão estes os
}

99 Manuel Borges CARNeIRO, Portugal Regenerado em 1820, 3. ${ }^{a}$ edição, Lisboa, Typografia Lacerdina, 1820, p. 76.

100 José Theotonio Canuto de ForJó, Memoria em que deo o seu parecer ao convite das Juntas do Governo Supremo do Reino em 24 de Octubro, Lisboa, Impressão de Alcobia, 1820, p. 20.

101 Francisco José de Almeida, Introdução à Convocação das Cortes Debaixo das Condições do Juramento Prestado pela Nação, Offerecida ao Governo no dia 25 de Outubro de 1820, Lisboa, Impressão Régia, 1820, pp. 34 e 46.

102 José de ARriaga, História da Revolução Portugueza de 1820, vol. 2, Porto, Livraria Portuense, 1887, pp. 190 e ss.

103 Documentos para a Historia das Cortes Geraes da Nação Portugueza, op. cit., p. 79. 
patriarchas da nação, os fundadores da patria e os alicerces do estado. Considerai e elegei"104.

Este manifesto é acompanhado pelo "novo plano de representação nacional”, as instruções eleitorais de 31 de Outubro de 1820, para regular as eleições de deputados que vão formar as Cortes extraordinárias e constituintes. Estava encetado o novo sistema eleitoral, que vamos tratar de seguida. Sem embargo, a lei de 4 de Junho de 1824, ainda vai repor em vigor as antigas Cortes, compostas pelos três estados do reino, as quais seriam convocadas conforme à antiga prática, foros e usos da nação ${ }^{105}$. Mas esta convocação não viria ser posta em prática até ao decreto de 3 de Maio de 1828, que vai dar azo às últimas eleições tradicionais das Cortes portuguesas ${ }^{106}$. Por outro lado, não se pode deixar de ter em conta que, de uma certa forma, a Carta Constitucional de 1826 -o texto constitucional que, até hoje, mais tempo se manteve em vigor- recuperou a representação parlamentar dos estamentos privilegiados através da Câmara dos Pares.

\section{O NOVO SISTEMA ELEITORAL VINTISTA.}

Quando a 31 de Outubro de 1820, a Junta Provisional do Governo Supremo do Reino e a Junta Provisional Preparatória das Cortes emitem um Manifesto aos Portugueses e dão a conhecer as primeiras Instruções, para a realização das eleições conducentes à formação das Cortes Constituintes, uma profunda discussão se iria manter sobre o sistema eleitoral que devia dar corpo ao novo modelo de representação política ${ }^{107}$, desejado pelos revolucionários liberais. Uma discussão a que não era alheio o confronto entre a clara vontade de edificar um regime que vivesse, "sob o império da lei criada pelos representantes da vontade nacional”, e as não menos claras "dificuldades inerentes à implantação, no terreno, de um tipo de representação que, ao instituir os eleitos como intérpretes da vontade de toda a nação", iria contender com uma realidade social distinta. Uma realidade social, em que "as dependências se mantinham, (...) mediadas por arreigados sentimentos de pertença a corpos sociais intermédios"108. Compreender, pois, a génese e a evolução do sistema eleitoral vintista implica desde logo não ignorar os confrontos e as tentativas de conciliação entre os principios e a realidade, entre os fins propostos e os meios encontrados para os alcançar.

Significa isto, que se queremos conhecer o sistema eleitoral nesta época escolhido, não devemos esquecer que este visava traduzir não só aquilo que os

104 Documentos para a Historia das Cortes Geraes da Nação Portugueza, op. cit., pp. 80-83.

105 O Padre Amaro ou Sovela Política, Histórica e Literária. Periódico Mensal Dedicado a Todos os Portugueses de Ambos os Mundos, Londres, Greenlaw, 1824, pp. 216-223.

106 Collecção de todas as Leis, Alvarás, Decretos, etc. Impressos na regia Officina Typografica, $1 .^{\circ}$ Semestre de 1828, Parte $1 .^{a}$, Lisboa, Impressão Regia, 1828, pp. 5-6.

107 Modelo que tinha nas eleições a "condição essencial do governo representativo (...) opondo-se ao método tradicional da representação estamental em Cortes”. Maria NAMORADO e Alexandre Sousa Pinheiro, Legislação Eleitoral Portuguesa - Textos Históricos (1820-1974), t. I, Lisboa, Comissão Nacional de Eleições, 1998, p. 9.

108 Fernando CATrogA, "Os Pais da Pátria Liberal", in Revista de História da Sociedade e da Cultura 8, 2008, pp. 252-253. [Disponivel em: http://hdl.handle.net/10316.2/39673 (consultado no dia 17 de Abril de 2017)]. 
detentores do poder politico tinham em mente alcançar, como as possibilidades que as circunstâncias lhes ditavam facilitando ou dificultando o percurso do caminho pretendido. Se a ideia, para ser concretizada, não pode desconhecer nem o contexto em que se apresenta, nem o destinatário a que se dirige, também a análise dos meios colocados ao seu serviço tem de ser devidamente enquadrada para melhor ser entendida. É assim, com base nestes pressupostos, que nos propomos nas páginas seguintes ir ao encontro do sistema eleitoral relativo à eleição de Deputados, percorrendo e confrontando as opções feitas desde as Instruções eleitorais de 31 de Outubro de 1820, até à Constituição de 23 de Setembro de 1822. A nossa análise, reiteramo-lo, privilegiará o sistema eleitoral $^{109}$, abordando em concreto o modo de eleição dos Deputados, o tipo de sufrágio e de voto dados pelos eleitores, bem como o método de escrutínio, sem que isso signifique ignorar ou descurar outras importantes questões atinentes ao direito eleitoral110, nomeadamente as que se reportam à capacidade eleitoral, activa e passiva, bem como ao recenseamento. Nestes termos, vamos então perceber o trilho percorrido desde a primeira lei eleitoral até à primeira Constituição do período vintista, passando pelas Instruções de 22 de Novembro de 1820 e pelo Projecto de Constituição de 15 de Junho de 1821. Subsidiariamente faremos referência à alteração feita ao projecto de Constituição, no capítulo relativo à eleição dos Deputados, alteração apresentada em Abril de 1822, e à Lei eleitoral de 11 de Julho de 1822, mas apenas para assinalarmos os mais relevantes passos dados neste dominio. Consideramos que a investigação sobre as soluções contidas nas Instruções de 31 de Outubro, de 22 de Novembro, no Projecto de Constituição e, finalmente, na própria Constituição, não só nos ajuda a verificar como foi evoluindo a construção do primeiro sistema eleitoral do liberalismo português, como nos auxilia na descoberta dos encontros e desencontros, que envolveram quer os revolucionários de Agosto e de Setembro de 1820, quer, posteriormente, os próprios constituintes. E consideramos ainda, que esta investigação voltada essencialmente para o sistema eleitoral, nos permite reforçar a ideia de que para os liberais daquele tempo, na senda de Cícero, havia um "principio que sempre deve ser mantido num Estado - que os mais numerosos não valham mais"111, pelo que nunca se poderia confundir, como sustentou Serpa Pimentel, "a eschola radical e theorica, a da extrema democracia, ou da soberania do numero (...) e a do bom senso e da soberania da razão"112.

109 Sistema eleitoral aqui entendido, como "a totalidade das normas, das técnicas e dos procedimentos que se aplicam desde a abertura do processo eleitoral até à proclamação dos resultados, neles se incluindo os modos de distribuição dos assentos parlamentares". Ricardo Leite PINTO, José de Matos CORREIA e Fernando Roboredo SEARA, Ciência Política e Direito Constitucional, 4ª ed., revista e ampliada, Lisboa, Universidade Lusiada Editora, 2009, p. 361 (a obra aqui referenciada tem já uma $5^{a}$ ed., revista, de 2013, mas que apenas contempla o vol. I, no qual esta matéria não é abordada).

110 Sobre o direito eleitoral, seguimos o entendimento de que ele traduz "o conjunto de comandos jurídicos, positivos ou consuetudinários, que regulam a designação por sufrágio de representantes para cargos políticos”. Ricardo Leite PINTO, José de Matos CoRREIA e Fernando Roboredo SEARA, Ciência Politica e Direito Constitucional, op. cit., p. 361.

111 Cícero, Tratado da República (trad. para a lingua port., de Francisco de OlIVEIRA, do original De Re Pvblica), Lisboa, Círculo de Leitores, 2008, p. 146.

112 António de Serpa Pimentel, Questões de Política Positiva - Da Nacionalidade e do Governo Representativo, Coimbra, Imprensa da Universidade, 1881, p. 197. 
Assim, e de acordo com o que anteriormente dissemos, vamos ao encontro das soluções definidas sobre: (i) o modo de eleição dos Deputados, o que significa identificar a opção feita ou pela eleição com vários graus ou pela eleição directa; (ii) a modalidade do voto, o que implica compreender se o sufrágio era oral ou secreto, e no caso de ser oral se obedecia a alguma especifica particularidade, bem como em que circunstâncias o voto era uninominal ou plurinominal; (iii) o citério de atribuição dos mandatos, o que nos permite perceber se na mesma eleição existia apenas uma ou mais modalidades de apuramento dos votos.

\section{O modo de eleição dos Deputados.}

Oscilando entre a existência de dois ou mais graus, quer as Instruções de Outubro de 1820, quer as de Novembro do mesmo ano, quer ainda o projecto de Constituição apresentado às Cortes ${ }^{113}$, não mostraram abertura à possibilidade da eleição directa dos Deputados. Não obstante as diferenças existentes entre os três documentos, e a circunstância de no primeiro (Instruções de Outubro) e no terceiro (Projecto de Constituição), as eleições se processarem em dois graus, ao contrário das Instruções de Novembro que já optavam pela eleição em mais graus, a todos unia a ideia de "que el sufrágio indirecto asegura y garantiza una mejor selección, atenua el ardor de las luchas electorales, evita las improvisaciones y los impulsos irreflexivos"114. Estávamos no fundo, como sublinhou Hamilton, diante a perspectiva de que a eleição dos representantes da Nação deveria ser "feita pelos homens mais capazes de analisar as qualidades adaptadas ao cargo", pelo que "um pequeno número de pessoas, seleccionadas pelos seus concidadãos de entre a massa global, terá mais probabilidade de possuir a informação $e$ o discernimento exigidos para tão complicados investigações"115. Tratava-se afinal de garantir, como Fernández Sarasola séculos mais tarde veio dizer, uma representação em que só "los más idóneos, aquellos que por sus condiciones particulares se hallasen supuestamente en la situación de expresar la voluntad general"116, pudessem efectivamente escolher os Deputados da Nação.

É pois, seguindo estes principios que surgem as Instruções de 31 de Outubro de $1820^{117}$, dizendo que "para se formar a representação nacional, cumpre que haja Eleições de Eleitores e Eleições de Deputados" (art. 1 19) e esclarecendo que "as Eleições dos Eleitores serão feitas na camara cabeça do

113 Projecto concluído, como referimos, a 15 de Junho de 1821, apresentado às Cortes no dia 25 do mesmo mês e publicado em Janeiro de 1822. Diário das Cortes Geraes Extraordinárias e Constituintes da Nação Portugueza, t. 5, Lisboa, Imprensa Nacional, 1822, pp. 5-8. A discussão deste projecto teve início a 9 de Julho de 1821. Diário das Cortes Geraes Extraordinarias da Nação Portuguesa, Sessão de 9 de Julho de 1821.

114 Léon Duguit, Manual de Derecho Constitucional [trad. para a língua espanhola, de José G. ACUÑA, do título original Manuel de Droit Constitutionnel, Paris, Fontemoing, 1911], Granada, Editorial Comares, 2005, p. 149.

115 Alexander Hamilton, "O Modo de Eleição do Presidente", in Alexander HAMilton, James MADISON, John JAY, O Federalista, [trad., int. e notas, de Viriato Soromenho MARQUES e João C. S. DUARTE], 2 ${ }^{\mathrm{a}}$ ed., Lisboa, Fundação Calouste Gulbenkian, 2011, p. 604.

116 Ignacio FERNÁNDEZ SARASOLA, "Voluntad general y representaciónen el constitucionalismo iusracionalista", in Revista da Facultad de Derecho y Ciencias Politicas, v. 36, n 105 , MedelinColumbia, Julio-Diciembre de 2006, p. 265.

117 Instruções de 31 de Outubro de 1820, in Diário do Governo, $\mathrm{n}^{\circ}$ 23, de 10 de Novembro de 1820. 
districto respectivo; as dos Deputados serão feitas pelos Eleitores na casa da camara da cabeça da comarca" (art. $2^{\circ}$ ). Quanto ao direito de voto era distinta a solução encontrada para cada um dos graus eleitorais, uma vez que enquanto no primeiro grau esse direito era estendido a "todos os Chefes de família domiciliarios dos respectivos districtos" (art. $9^{\circ}$ ), não se lhes exigindo nenhuma condição literária ou censitária, já no segundo grau, ao definir-se que os Eleitores de Comarca teriam de escrever o nome do Deputado que escolheriam (art. $21^{\circ}$ ), se assumia que eles deveriam necessariamente saber ler e escrever. No fundo, quando estas Instruções estipulavam que para poderem ser eleitos Eleitores de Comarca, os cidadãos precisariam de ter "virtudes, e intelligencia" (art. 11 ${ }^{\circ}$ ), estavam objectivamente a indicar que ter virtudes e inteligência é também saber ler e saber escrever e que sem virtudes e inteligência, o Eleitor de Comarca não poderá simplesmente exercer o seu direito de voto na eleição dos Deputados. Deste modo, conciliando o art. $11^{\circ}$ (capacidade eleitoral passiva no primeiro grau), com o art. $21^{\circ}$ (capacidade eleitoral activa no segundo grau), talvez evitemos a afirmação segundo a qual as Instruções de Outubro revelavam "de um modo primitivo a implantação de um sistema de voto capacitário no pólo passivo"118. $\mathrm{E}$ talvez o evitemos se interpretarmos este "sistema de voto capacitário no pólo passivo", à luz do que se prescreve para o tipo de voto exigido na escolha dos Deputados. Parece-nos não haver lugar a qualquer dúvida, de que devendo esse voto ser escrito por cada Eleitor de Comarca (art. $21^{\circ}$ ), se estava a condicionar a pertença a este segundo colégio eleitoral apenas a quem soubesse ler e escrever. Dito de outro modo, ao exigir-se que quem vota saiba escrever, por maioria de razão se está a dizer que aquele que é eleito para posteriormente votar, também o deve saber. Logo, se o eleito na eleição de primeiro grau é ele próprio o Eleitor na eleição de segundo grau, as condicionantes capacitarias a que está sujeito são também as mesmas. Não faria sentido que se dissesse que cada Eleitor de Comarca "hirá escrever o nome do que elege" (art. 21\%), se ele próprio não soubesse ler, nem escrever. Este aspecto não é no nosso entendimento passível de desvalorização, porque quando estamos perante eleições realizadas por vários graus, não poderemos deixar de avaliar a capacidade eleitoral activa e passiva requerida para cada um dos graus existentes. Se há vários graus, há inevitavelmente vários colégios eleitorais com regras que podem ser distintas, pelo que em sistemas eleitorais com estas caracteristicas devemos sempre verificar se as condições existentes para a atribuição da capacidade eleitoral no primeiro grau, se mantêm no grau ou nos graus sucessivos.

Estamos perante algo que não pode deixar de ser analisado nas Instruções de 31 de Outubro, até para melhor percebermos as razões da contestação que sofreram. Essa contestação, ou pelo menos uma das suas partes mais visiveis, poderá não ter sido apenas motivada pela crítica aos requisitos colocados para a eleição quer de Eleitores de Comarca, quer dos Deputados ${ }^{119}$, quando se afirmava

118 Alexandre Sousa PINHEIRO, “A capacidade eleitoral no direito português de 1820 a 1974 ”, p. 10 [Disponivel em: http://www.cne.pt/sites/default/files/dl/trabalho_capacidade_eleitoral.pdf (consultado no dia 19 de Abril de 2017)].

119 Como parece sugerir Alexandre Sousa Pinheiro, quando para reforçar a ideia, a que já aludimos, de que as Instruções de 31 de Outubro evidenciavam de um "modo primitivo a implantação de um sistema de voto capacitário no pólo passivo”, considera que essa característica é ainda mais saliente nas exigências colocadas para aqueles que venham a ser Deputados. Alexandre Sousa PINHEIRO, "A capacidade eleitoral no direito português de 1820 a 1974", op. cit., p. 10 . 
que estes deveriam ter "a maior somma possivel de conhecimentos scientificos", para além de possuirem "meios honestos de subsistência" (art. 26"). Na nossa opinião, o que terá estado em causa nessa contestação era não só a recusa dos requisitos impostos para a obtenção da capacidade eleitoral passiva nos dois graus, como também a rejeição daqueles que se exigiam para a aquisição da capacidade eleitoral activa no segundo grau das eleições, ou seja, nas condições impostas àqueles que poderiam eleger os próprios Deputados. E é neste contexto que também devemos entender os contestatários das Instruções de 31 de Outubro, quando afirmaram que com a adopção destas Instruções, "a nação nem é plena nem livremente representada", e "não se apuram e refundem, como cumpre, eleitores e deputados". Havia assim, de acordo com esta posição, "absoluta necessidade para o bem da nação que os deputados de côrtes fossem eleitos pelo methodo e com as mesmas circunstancias prescriptas na constituição hespanhola", pelo que era fundamental que esta fosse decretada e mesmo que posteriormente viesse a ser modificada, não se lhe introduzissem normas que alterassem "o seu essencial e as idéas liberaes que ella contém"120. Estavam afinal em confronto não só dois modos distintos de eleição dos Deputados, destes e dos próprios Eleitores de Comarca a quem era concedida a função de os eleger, como duas formas diferentes de encarar o âmbito e o conteúdo da capacidade eleitoral, fosse ela activa ou passiva. Mesmo sem se contrariar a ideia, segundo a qual "o eleitorado é uma função, exigindo, em consequencia, garantias e capacidades"121, ideia que tinha tradução objectiva na eleição por graus, a defesa do modelo seguido na Constituição espanhola apresentava-se como menos exigente no plano da definição da capacidade eleitoral, logo mais liberal, na selecção quer dos próprios Eleitores, quer dos próprios Deputados ${ }^{122}$.

Com efeito, o sistema eleitoral aí definido, ao não impor restrições capacitárias ou censitárias ${ }^{123}$, surgia aos olhos dos contestatários portugueses como muito mais condicente com os objectivos da revolução liberal iniciada em Agosto de 1820, no Porto. É certo, que o facto de existirem mais colégios eleitorais do que os previstos nas Instruções de Outubro, restringia consideravelmente o número daqueles sobre quem recaía a escolha dos Deputados, mas isso pareceu ser questão menor face à ausência de outro tipo de exigências. A circunstância da integração nos primeiros colégios eleitorais, como referiu Ramón Salas, estar "al alcance de cualquier hombre de un talento comum", mesmo que se requeresse para

120 Documentos para a Historia das Cortes Geraes da Nação Portugueza, op. cit., p. 96.

121 José Joaquim Lopes PRAÇA, Direito Constitucional Portuguez, vol. II [publicação facsimilada do trabalho de Lopes PRAÇA, Direito Constitucional Portuguez - Estudos Sobre a carta Constitucional de 1826 e Acto Addicional de 1852, 2 ${ }^{\mathrm{a}}$ Parte, 1879] Boletim da Faculdade de Direito da Universidade de Coimbra, Coimbra, Coimbra Editora, 1997, p. 91.

122 Sobre a eleição dos Deputados às Cortes espanholas, cf. Constituição Política da Monarquia Hespanhola [traduzida em portuguez por A. M. F.], Coimbra, Real Imprensa da Universidade, 1820, pp. 12-25.

123 Refira-se que apesar de ter declarado suspensa a norma que exigia para os Deputados, "uma renda annual proporcionada", a Constituição espanhola não deixava de também a prever (arts. $92^{\circ}$ e $93^{\circ}$ ), o que demonstra como a relação entre a existência de rendimento e o exercício do poder político, não era questão menor. Situação aliás que, em Portugal, as Instruções de 22 de Novembro igualmente seguiriam, ao definirem numa adenda ao artigo que definia a necessidade de rendimento para os candidatos a Deputados, que esse artigo "não tem agora applicação". 
o último colégio "una sagacidad y un discernimiento que se hallaen pocos"124, seria suficiente para que o espírito liberal dos contestatários portugueses ficasse tranquilo. Para eles, como muito mais tarde diria Joel Serrão, a Constituição espanhola surgia como "o começo peninsular da mutação liberal"125, e isso era o mais importante.

Tínhamos assim de um lado, as Instruções de 31 de Outubro definindo, nos termos descritos, a eleição dos Deputados em dois graus, do outro, a Constituição espanhola de 1812, estipulando quatro tipos distintos de escolha de representantes, ou seja quatro graus eleitorais ${ }^{126}$, sem se exigir para os Cidadãos espanhóis que neles poderiam participar, nenhum requisito capacitário ou censitário. Seguindo este modelo, e para ir ao encontro dos contestatários das Instruções de 31 de Outubro, seriam decretadas, a 22 de Novembro, novas Instruções para a eleição das Cortes Constituintes. Umas Instruções que copiando quase na integra a Constituição gaditana ${ }^{127}$, mandavam convocar para as eleições "todos os homens, maiores de 25 annos, Seculares, ou Ecclesiasticos Seculares"128, e que também não limitavam a presença em nenhum dos graus eleitorais (na eleição de Compromissários, na eleição dos Eleitores de Freguesia, na eleição dos Eleitores de Comarca e na eleição de Deputados), a qualquer critério que não fosse o de ter o estatuto de Cidadão.

Mas se este foi o desfecho da agitação provocada pelas Instruções de 31 de Outubro, há algumas perguntas que devemos fazer se quisermos compreender, na essência, o caminho percorrido até à consagração do sistema eleitoral escolhido pela Constituição de 1822. E essas perguntas são as seguintes: o que teria levado a Junta Governativa a optar por uma eleição em dois graus, nas condições mencionadas, e a não perfilhar logo o modelo da Constituição espanhola? Ter-se-iam os elementos da Junta inspirado na Constituição francesa de 1791, ela própria instituidora de um sistema eleitoral de dois graus ${ }^{129}$,

124 Ramón SALAS, Lecciones de Derecho Publico Constitucional, Madrid, Centro de Estudios Constitucionales, 1982, pp. 102-103.

125 Joel SERRÃO, "Democracia versus liberalismo", in Maria Halpern PEREIRA, Maria de Fátima Sá e Melo FERREIRA e João B. SERRA, O Liberalismo na Península Ibérica na primeira metade do século XIX, $1^{\circ}$ vol., Lisboa, Sá da Costa Editora, 1982, p. 5.

126 Ramón Salas falava inclusive de "quatro ou cinco graus". De acordo com a sua posição, a Constituição de Cádiz teria "tres ó mais bien cuatro ó cinco" graus: "pues las juntas parroquiales nombran los compromisarios, éstos nombram los electores de parroquia, éstos los electores de partido, éstos los electores de provincia, y éstos los diputados”. Ramón SALAS, Lecciones de Derecho Publico Constitucional, op. cit., p. 188. Quanto a nós, sem prejuízo de retomarmos o tema noutro momento do nosso trabalho, entendemos apenas falar de quatro graus, por considerarmos que a leitura das Instruções identifica os eleitores de comarca como os próprios eleitores de provincia.

$127 \mathrm{Na}$ apresentação das Instruções, podia ler-se: "a primeira columna d'estas instrucções é a traducção literal da constituição hespanhola”. Instruções de 22 de Novembro de 1820, in Diário do Governo, Suplemento, de 23 de Novembro de 1820.

128 Edital, in Collecção de Leis, Decretos, e Alvarás, Ordens Regias e Editaes, Lisboa, Regia Typografia Silviana, 1820, p. 404.

129 Estipulava esta, no seu Título III, Cap. I, Secção II, art. 1º, que "Pour former l'Assemblée national et législative, les citoyens actifs se réuniront tous les deux ans en Assemblées primaires dans les villes et dans les cantons", explicando depois no art. $1^{\circ}$, da Secção III, do mesmo Capítulo e do mesmo Título, que "Les électeurs nommés en chaque département se réuniront pour élire le nombre des représentants” [Disponivel em: http://www.conseil-constitutionnel.fr/conseil- 
preferindo desse modo o modelo gaulês ao gaditano? Ou, independentemente das razões evocadas, e que analisaremos de seguida, as Instruções de Outubro foram pensadas como a via possivel para a futura adopção das eleições directas? Estas questões não são quanto a nós irrelevantes, porque apesar de tantas vezes se desvalorizarem as Instruções de 31 de Outubro, precisamente pelo facto das eleições para as Cortes Constituintes terem sido convocadas pelo critério da Constituição espanhola, o certo é que muitas das ideias inscritas nessas Instruções regressariam mais tarde, o que significa que a sua substituição a 22 de Novembro pode apenas ter correspondido a uma necessidade conjuntural. Vamos, pois, por partes.

Quanto à questão sobre uma eventual rejeição do sistema eleitoral da Constituição espanhola e uma possível aproximação do sistema definido pela Constituição francesa de 1791, entendemos não ser taxativo pensar-se que os membros da Junta Governativa tenham liminarmente preferido o sistema francês e recusado o sistema espanhol, ou que não tenham até equacionado adoptar este. Mesmo que reconheçamos como podem ser precipitadas as interpretações que hoje fazemos das interpretações que ontem se fizeram - e aqui o ontem tem quase dois séculos - não deixa de ser pertinente assinalar quer a existência de pareceres, encomendados pela própria Junta e elaborados por pessoas que lhe eram próximas, nos quais se elogiavam as teses espanholas, quer a circunstância de muitas das soluções da Constituição francesa não terem sido adoptadas.

No primeiro caso, e após análise de um de esses pareceres ${ }^{130}$, percebemos que, não obstante se constatar uma identificação com a maioria das soluções preconizada pela Constituição espanhola, se considerava que a premência das eleições justificava uma resolução mais célere. Uma resolução que contemplando um menor número de graus eleitorais, implicando também menor morosidade processual, conduzisse a que o processo eleitoral decorresse num espaço de tempo mais curto. É isso que nos é revelado no parecer anteriormente referido, no qual se refere a necessidade de omitir "por esta vez somente uma eleição intermediaria para simplificar e abreviar a eleição dos deputados"131. Curiosamente, esta mesma preocupação com a celeridade do processo eleitoral estava presente no próprio Manifesto aos Portugueses quando, para justificarem a opção pelas Instruções de 31 de Outubro, os seus signatários esclareciam que "entre as varias plantas de eleições, (...), mereceu a preferencia aquella que, respeitando a verdadeira e legitima representação nacional, simplificava o systema e economisava o tempo". Ainda de acordo com as suas palavras, "qualquer outra de desenho mais complexo acarretaria comsigo delongas que, alem de serem pouco acceitas á bem intencionada impaciencia do publico, não se accommodariam com a imperiosa exigencia das circumstancias actuaes" 132 .

constitutionnel/francais/la-constitution/les-constitutions-de-la-france/constitution-de1791.5082.html (consultado no dia 18 de Abril de 2017)].

130 Referimo-nos ao parecer dado por Canuto de Forjó, a que já fizemos referência no segundo ponto do nosso trabalho. José Theotonio Canuto de FoRJó, Memoria em que deo o seu parecer ao convite das Juntas do Governo Supremo do Reino em 24 de Octubro, op. cit..

131 José Theotonio Canuto de FoRJó, Memoria em que deo o seu parecer ao convite das Juntas do Governo Supremo do Reino em 24 de Octubro, op. cit., p. 22.

132 Documentos para a Historia das Cortes Geraes da Nação Portugueza, op. cit., p. 82. 
No segundo caso, uma comparação entre o texto das Instruções de 31 de Outubro e o texto da Constituição francesa de 1791, leva-nos a compreender que o facto de a Junta Governativa ter optado pela eleição em dois graus, não implicou que tivesse preferido todas as soluções preconizadas pelos revolucionários franceses. Há aliás, não obstante essa coincidência nos graus eleitorais, elementos de significativa distinção entre os dois textos, desde logo no plano dos requisitos para a obtenção da capacidade eleitoral, seja no âmbito capacitário, seja no âmbito censitário. Sobre a condição capacitária, enquanto a Constituição francesa nada previa, as Instruções portuguesas definiam, como vimos, que quer os Eleitores de Comarca, quer os Deputados, soubessem ler e escrever; sobre a condição censitária, a separação é ainda mais notória não se registando qualquer coincidência nos critérios definidos. Enquanto as Instruções portuguesas impunham requisitos censitários aos Deputados, não os impondo aos eleitores do primeiro e do segundo graus, a Constituição gaulesa defendia precisamente o inverso. Com efeito, esta, aos Deputados nada exigia, considerando que "tous les citoyens actifs, quel que soit leur état, profession ou contribution pourront être élus représentants de la Nation"133, mas para os eleitores do primeiro e do segundo graus definia proventos específicos. Os das Assembleias primárias (primeiro grau), aqueles a quem era concedido o estatuto de cidadão activo, deveriam pagar uma determinada contribuição ${ }^{134}$, os dos Departamentos (segundo grau) deveriam ser proprietários ou possuir um certo rendimento ${ }^{135}$. Como escreveu Maurice Deslandres, sendo "rigoureuse pour l'électorat, la Constitution est facile pour l'éligibilité"136, seguindo assim solução bem diferente daquela que os liberais portugueses não só preferiram, como objectivamente adoptaram.

Consideramos, pois, procurando agora responder à possibilidade que adiantámos de as Instruções de Outubro terem sido pensadas como a via possivel para a futura adopção das eleições directas, que os elementos da Junta Governativa procurando conciliar, numa primeira fase, visões politicas distintas quanto ao modo de convocar eleições, tiveram essencialmente em vista encontrar a solução que mais se adequasse à realidade portuguesa. Uma solução que não inviabilizando o caminho para os seus objectivos futuros, afastasse o perigo de uma ruptura eminente.

E era essa solução manifestamente pouco liberal? Sim, por certo, para aqueles jovens oficiais que já tinham do liberalismo uma concepção mais próxima

133 Art. 3º Secção III, Cap. I, Título III, da Constituição francesa de 1791.

134 Definia o art. $2^{\circ}$, Secção II, Cap. I, Título III, da Constituição de 1791, que "Pour être citoyen actif, il faut: Payer, dans un lieu quelconque du Royaume, une contribution directe au moins égale à la valeur de trois journées de travail, et en représenter la quittance”. A esta exigência censitária para o próprio eleitorado, não seria estranha como referiu Pierre Lardinière, a perspectiva de que sendo "le droit de vote (...) chose si nouvelle pour tout le monde, l’électorat était si peu dans les moeurs que le regime censitaire paraissait être alors une concession enorme du pouvoir et semblait seul regime possible". Pierre Venault de LARDINIÈRE, Le Droit Électoral Pendant la Révolution Française, Poitiers, Courrier de la Vienne, 1912, p. 26.

135 De acordo com o art. $7^{\circ}$, Secção II, Cap. I, Título III, da Constituição de 1791, só poderia ser nomeado eleitor nas Assembleias Primárias, quem fosse proprietário ou tivesse determinado rendimento.

136 Maurice Deslandres, Histoire Constitutionnelle de la France de 1789 a 1870, t. I, reimp. de 1־édition de 1932, Paris, Librairie Edouard Duchemin, 1977, p. 82. 
do que seria a democracia, aqueles a quem Xavier de Araújo ${ }^{137}$ se refere como os "oficiais moços, activos e inteligentes, porém mais instruidos na história das repúblicas da Grécia e de Roma, do que da Europa (...); teóricos rigorosos $e$ inflexiveis, para os quais publicar uma Constituição é o mesmo que executá-la, e executá-la o mesmo que infiltrá-la nos costumes de uma nação". Não, seguramente, para aqueles que muito "cheios da sua nobreza e muito desejosos de influir nos negócios públicos"138anteviam que a sua influência e o seu poder diminuiriam. Partindo de pressupostos distantes, mas convergindo nas críticas às primeiras Instruções eleitorais liberais, o certo é que ambos os grupos conseguiram pôr em causa as Instruções de Outubro e as primeiras eleições, para as primeiras Cortes constituintes, seriam feitas de acordo com os preceitos da Constituição espanhola. A vontade inicial da Junta era forçada a ceder e as regras do primeiro acto eleitoral vintista não seriam apenas inspiradas no modelo gaditano, elas espelhavam a cópia integral desse mesmo modelo.

Contudo, a história não pararia e o modo de eleição dos Deputados, em dois graus, proposto pelas Instruções de 31 de Outubro regressaria à luz do dia, cerca de sete meses depois, quando a 25 de Junho de 1821 é entregue nas Cortes o Projecto de Constituição. Como refere Zília Osório de Castro, este projecto "retomava o principio estabelecido nas primeiras instruções (...), para regularizar a eleição dos deputados"139 e propunha que essa eleição se fizesse "por meio de duas juntas eleitoraes: uma que se reunirá nos concelhos, outra nas cabeças das comarcas"140. De novo se recuperava o modo de eleição em dois graus e a primeira Junta Governativa, ou o que dela restava, via as Instruções que tinha proposto em Outubro, a darem uma prova de vida e a demonstrarem que não tinham sido efémeras. Existiam mudanças é certo, nomeadamente quanto à idade para o exercício do direito de voto no primeiro grau, que passava para os 21 anos (art. $33^{\circ}$, do Projecto de Constituição) ${ }^{141}$, e quanto à ausência de requisitos capacitários para qualquer tipo de eleitores, mas reforçava-se a ideia de que não poderiam "ser eleitos Deputados (...) os que não tiverem renda sufficiente para sua sustentação, procedente de bens de raiz, commercio, industria ou emprego". Reassumia-se neste caso, e de forma bem mais explicita do que nas primeiras Instruções, ser "condição necessária da elegibilidade possuir-se rendimentos suficientes para seu próprio sustento, o que limitava às classes proprietárias de capital ou dos meios de produção e a certas profissões liberais a participação directa no exercício do poder politico" 142.

137 Referimo-nos a José Maria Xavier de Araújo, membro, logo em 23 de Agosto de 1820, da Junta Provisional do Governo Supremo do Reino.

138 Xavier de ARAúJo, A Revolução de 1820 - Memórias [reed. do original Revelações e Memórias para a História da Revolução de 24 de Agosto de 1820, e de 15 de Setembro do Mesmo Ano, publicado em 1846], Lisboa, Centro de História da Universidade de Lisboa - Caleidoscópio, 2006, p. 52 .

139 Zília Osório de CASTRo, Cultura e Politica. Manuel Borges Carneiro e o Vintismo, p. 195.

140 Art. $34^{\circ}$, do Projecto de Constituição, in Diário das Cortes Geraes Extraordinárias e Constituintes da Nação Portugueza, t. 5, Lisboa, Imprensa Nacional, 1822, p. 5.

141 De referir que não obstante se propor a capacidade eleitoral activa a partir dos 21 anos, só poderia ser eleito Eleitor de concelho e Deputado quem tivesse 25 anos completos $\left(\operatorname{arts} .55^{\circ}\right.$ e $74^{\circ}$, do Projecto).

142 Miriam Halpern PEREIRA, Das Revoluções Liberais ao Estado Novo, Lisboa, Editorial Presença, 1994, p. 44. 
Nestes termos, se podemos compreender o que disse Trindade Coelho, quando referiu que os constituintes quiseram "que a futura Constituição portugueza não fosse menos liberal que a Constituição hespanhola, a qual, de resto, tiveram constantemente diante dos olhos ao fazerem a nossa"143, já não devemos esquecer que os objectivos para o modo de eleição dos Deputados foram, em muitos aspectos, distintos. Foram distintos quando, logo no início, através das Instruções de 31 de Outubro foi feita a opção pela eleição dos Deputados em dois graus, continuaram a ser distintos quando, pouco meses depois da eleição, se deu a conhecer o Projecto de Constituição, e mantiveram-se distintos quando, no texto final da Constituição se optou pela eleição directa. O que afirmamos, em nada prejudica o reconhecimento da preferência ou influência que noutros dominios a Constituição espanhola teve nas Cortes Constituintes. Esse facto foi aliás bem salientado pelo Deputado Borges Carneiro, ao mencionar que os redactores do projecto de Constituição "laborárão (...), sobre a Constituição de França de 1791, sobre a dos Estados Unidos da América, sobre a de Hespanha; $e$ não tiverão nem anglomania nem hispanomania; mas a terem de declarar alguma preferencia, estimão antes o liberalismo da Constituição hespanhola, que o feudalismo da ingleza"144. Porém, uma coisa será a análise dessa preferência sobre temas como a soberania, a divisão e a relação de poderes, ou os direitos individuais $^{145}$, outra será a observação sobre o sistema eleitoral em geral e, em particular, o modo de eleição dos Deputados, mesmo que nesse sistema possamos encontrar pontos de particular coincidência.

Todavia, esses pontos de particular coincidência não anulam o facto de neste específico domínio, o único momento em que os membros mais proeminentes da primeira Junta Governativa, e posteriormente deputados nas Cortes Constituintes ${ }^{146}$, plenamente seguiram a Constituição espanhola foi na convocação das Cortes Constituintes, e não apenas por razões directamente relacionadas com o sistema eleitoral aí proposto. Acresce, que a própria ponderação em torno das eleições directas, como sistema alternativo ao da eleição por graus, não deixou de estar presente após a revolução. É isso que constatamos pela leitura do Manifesto, quando os seus subscritores ao justificarem a escolha pela eleição dos Deputados em dois graus eleitorais e ao explicarem as razões para não adoptarem o modelo espanhol, afirmaram que não "convinha tomar $a$ mais singela, a fim de precaver que os vários corpos eleitoraes por sua mui carregada multidão dessem azo a tumultos e confusões"147. Percebe-se assim, como já tínhamos sugerido, que ao optarem pelo modelo inscrito nas Instruções de 31 de Outubro, os membros da Junta Governativa quiseram seguir uma solução intermédia. Uma solução que, ajudando a garantir o equilíbrio entre os

143 Trindade Coelho, Manual Político do Cidadão Portuguez, $2^{\text {a }}$ ed., Porto, Typographia A VAP., 1908, p. 190.

144 Deputado Borges Carneiro, in Diário das Cortes Geraes e Extraordinarias da Nação Portuguesa, Sessão de 17 de Abril de 1822, p. 834.

145 Sobre a influência da Constituição de Cádiz, nas Cortes Constituintes portuguesas, nomeadamente nos temas assinalados, consideramos de grande relevo o trabalho feito por José SÁNCHEZ-ARCILLA BERNAL, "La experiencia constitucional gaditana y la Constitución portuguesa de 1822", in Cuadernos de Historia Contemporánea, vol. 24, 2002, pp. 105-143.

146 Dos quais se destaca Manoel Fernandes Thomaz, cuja assinatura está presente em todos os documentos relativos ao sistema eleitoral.

147 Documentos para a Historia das Cortes Geraes da Nação Portugueza, op. cit., p. 82. 
que queriam um colégio eleitoral mais restrito para a escolha final dos Deputados e os que desejavam já a eleição directa, não pusesse em causa a própria eleição das Cortes constituintes, deixando a estas a decisão final quanto ao modelo a adoptar.

$\mathrm{E}$ foi com estes antecedentes, que os constituintes deram lugar ao debate sobre o modo de eleição dos Deputados, um debate que incidia sobre a "parte mais importante do projecto da Constituição; por mais excellente que for a Constituição"148. Se a todos poderia unir a vontade de "alterar substancialmente a ideia de soberania", uma vontade espelhada na "institucionalização de um novo modelo de parlamento - Cortes constituintes - composto por Deputados eleitos por sufrágio" 149 , o mesmo não se verificava quanto ao modo como esse sufrágio se haveria de manifestar. A decisão não era fácil, numa época em que pelo facto de muitos considerarem estar "la educación política en estado embrionário o de escaso desarrollo", se pensava que o "más prudente seria estabelecer el sufrágio de dos grados"150. E não o era ainda, quando também muitos acreditavam que a eleição indirecta permitia, num primeiro momento "o voto universal em toda a sua simplicidade lógica e abstracta", enquanto numa segunda fase se estabeleceriam "limites de capacidade, fundados nas condições de fortuna, de instrucção ou de independencia social"151. Estava afinal em causa saber, como perguntava nas Cortes o Deputado José Ferreira de Moura, "quem será mais capaz de escolher bem? Poucos cidadãos ilustrados (...), ou o povo?", aquele que pode ver para lá da espuma dos acontecimentos ou aquele que "para sempre na superficie das cousas"152?

Para os defensores deste tipo de eleição, a resposta não oferecia dúvidas. Admitiam até, como enfatizou Borges Carneiro, que "a eleição directa pode considerar-se melhor em quanto se considera mais livre, e como aquella, em que o povo perde menos os seus direitos", sem, contudo, deixarem de alertar que "nem sempre o que he mais livre (...) seja o melhor, porque se este principio fosse verdadeiro, seria melhor que o povo fizesse as leis"153. Para estes opositores da eleição directa, não deixaria de estar presente a ideia, muito mais tarde referida por Hayek, segundo a qual o liberalismo "acepts majority rule as a method of deciding, but not as an autority for what the decision ought to be"154.

148 Deputado Sarmento, in Diário das Cortes Geraes e Extraordinarias da Nação Portuguesa, Sessão de 27 de Agosto de 1821, p. 2030.

149 José Domingues, “A Soberania num Manuscrito Português de 1837”, in e-SLegal History Review 22, 2016, p. 15 [Disponivel em:

http://www.iustel.com/v2/revistas/detalle_revista.asp?z=5\&id=15 (consultado no dia 29 de Abril de 2017)].

150 Léon Duguit, Manual de Derecho Constitucional, op. cit., p. 149.

151 António de Serpa Pimentel, Questões de Política Positiva - Da Nacionalidade e do Governo Representativo, op. cit.,p. 198.

152 Deputado José Ferreira de Moura, in Diário das Cortes Geraes e Extraordinarias da Nação Portuguesa, Sessão de 29 de Agosto de 1821, p. 2075.

153 Deputado Borges Carneiro, in Diário das Cortes Geraes e Extraordinarias da Nação Portuguesa, Sessão de 29 de Agosto de 1821, p. 2079.

154 Friedrich A. HAYEK, The Constitution of Liberty, Chicago, University of Chicago Press, 1978, p. 104. 
E do lado dos partidários da eleição directa? Para estes, como afirmava o Deputado Sarmento, o sufrágio directo era o mais "liberal possivel", aquele que " $a$ historia antiga, e moderna prova que não ha motivo, que faça impossivel a existencia de uma unica delegação, e esta immediata. Na Grecia, Roma, em Inglaterra, e na America Ingleza vemos que se admittirão as eleições directas" 155. Defender o sistema contrário, significaria dizer, como reforçava o Deputado Guerreiro, que "os deputados das cortes (...) nunca se podem dizer representantes da nação, que os não escolheu", e implicará esquecer que só "póde amar-se o systema constitucional (...) quando nelle se achão as grandes vantagens que elle offerece, e uma dellas sem duvida he a que provem das eleições directas" ${ }^{156 .}$ Tratava-se em suma de perceber, como diria Stuart Mill, "if the primary electors did to any extent leave to their nominees the selection of their Parliamentary representative, - the voter would be prevented from identifying himself with his member of Parliament, and the member would feel a much less active sense of responsibility to his constituents"157. Algo que Lopes Praça não deixaria de realçar, quando esclareceu que "as eleições indirectas são menos próprias para o desenvolver o espirito publico e a intelligencia politica" 158 , pelo que a identidade do novo regime não poderia prescindir da escolha directa dos Deputados.

Aos constituintes patrocinadores desta causa acompanhava a nível internacional, no âmbito dos Estados com Constituições escritas, a Constituição norte-americana de $1787^{159}$, uma vez que a Constituição francesa de 1793, uma "Constitution mort-née" 160 , que também previa a eleição directa dos Deputados ${ }^{161}$, não tinha logrado ser aplicada. É, pois, com este enquadramento e após intensa discussão, que a 29 de Agosto de 1821, nas Cortes constituintes, a eleição directa receberia 66 votos a favor e apenas 22 contra $^{162}$, o que permitiu posteriormente

155 Deputado Sarmento, in Diário das Cortes Geraes e Extraordinarias da Nação Portuguesa, Sessão de 27 de Agosto de 1821, p. 2030.

156 Deputado Guerreiro, in Diário das Cortes Geraes e Extraordinarias da Nação Portuguesa, Sessão de 29 de Agosto de 1821, p. 2080.

157 John Stuart MiLl, Considerations on Representative Government, London, Savill and Edwards, Printers, 1861, p. 188.

158 José Joaquim Lopes PRAÇA, Direito Constitucional Portuguez, op. cit., p. 93.

159 Constituição norte-americana, de 1787, Art. I, Secção II, nº 1 [Disponivel em: http: / / www.modern-

constitutions.de/nbu.php?page_id=02a1b5a86ff139471c0b1c57f23ac196\&show_doc=US-001787-09-17-en\&viewmode=pages\&position=0 (consultado no dia 29 de Abril de 2017)]. De referir que não obstante a estatuição da eleição directa dos membros da Câmara dos Representantes, as eleições para o Senado obedeciam, até 1913, a um sistema distinto, uma vez que os Senadores de cada Estado eram eleitos pelas respectivas legislaturas, como consta do Art. $1^{\circ}$, Secção 3, $\mathrm{n}^{\circ} 1$, da referida Constituição. Ao facto também não terá sido alheia, como refere Ricardo Leite PINTO, "a tensão entre a democracia populista e a democracia aristocrática ou elitista”. Ricardo Leite PINTO, A Democracia Constitucional nos E. U. A., Lisboa, Universidade Lusiada Editora, 2013, p. 15.

160 Pierre Venault de LARDINIÈRE, Le Droit Électoral Pendant la Révolution Française, Poitiers, Courrier de la Vienne, 1912, p. 284.

161 Arts. $8^{\circ}$ e 23, da Constituição de 1793 [Disponivel em: http://www.conseilconstitutionnel.fr/conseil-constitutionnel/francais/la-constitution/les-constitutions-de-lafrance/constitution-du-24-juin-1793.5084.html (consultado no dia 20 de Abril de 2017)].

162 Diário das Cortes Geraes e Extraordinarias da Nação Portuguesa, Sessão de 29 de Agosto de 1821 , p. 2082. 
alterar todo o capítulo respeitante à eleição dos Deputados ${ }^{163}$, do projecto de Constituição.

Surgiria assim nesse projecto, um novo art. $42^{\circ}$ e nele a indicação de que " $a$ eleição se fará directamente á pluralidade de votos, dados em escrutinio secreto pelos cidadãos reunidos em assembléas eleitoraes". Ficava consagrado, nas palavras de um deputado constituinte, "um systema novo que ainda não appareceu em nação nenhuma, tal qual nós o adoptamos"164. E seria a partir deste articulado, mesmo sem o texto final da Constituição estar concluído que, a 11 de Julho de 1822 , se publica uma nova Lei eleitoral ${ }^{165}$ a definir as regras de eleição da futura legislatura. Esta, repetindo no seu art. $22^{\circ} 166$, o que já constava da nova versão do projecto de Constituição, limitar-se-ia a antecipar o que passaria a constar no futuro art. $42^{\circ} 167$, da Lei Fundamental portuguesa. Uma Lei Fundamental que, ao assumir a eleição directa dos Deputados, permitiria que mais tarde se afirmasse que a nossa Constituição de 1822 "deu passos, (...), que não a deixam, de modo nenhum, atrás da experiência constitucional coeva $e$ anterior, europeia e internacional"168. Uma Constituição, que à luz de muito do que é actualmente seguido em matéria eleitoral no nosso país, nos permite nela "reconhecer um parentesco em linha recta"169. Para trás ficavam umas Cortes Constituintes, cujos Deputados apesar de eleitos por um sistema eleitoral em quatro graus tinham, por expressiva maioria, decidido que a futura eleição se faria por sufrágio directo, abrindo desse modo as portas do futuro.

\section{A modalidade do voto.}

Escreveu Hauriou que "le suffrage, c'est l'organisation politique de l'assintement, c'est-à-dire de cette operátion de la volonté qui consiste à accepter ou à ne pas accepter une proposition faite ou une décision prise par un autre pouvoir" ${ }^{170}$, pelo que a forma como o sufrágio se expressa, e o modo como o voto se transmite, nunca são indiferentes quer para a identificação das regras gerais a que uma eleição está sujeita, quer para a caracterização do próprio sistema

163 Publicado a 16 de Abril de 1822. Diário das Cortes Geraes e Extraordinarias da Nação Portuguesa, Sessão de 16 de Abril de 1822, pp. 813-815.

164 Deputado Miranda, in Diário das Cortes Geraes e Extraordinarias da Nação Portuguesa, t. VI, Sessão de 8 de Maio de 1822, p. 102.

165 Esta lei eleitoral de 11 de Julho de 1822, seria pioneira na previsão da existência de Livros de Matrícula nas freguesias, nos quais deveriam estar inscritos os Cidadãos com direito de voto. "Surgiam desta forma, em Portugal, os primeiros cadernos de inscrição para actos eleitorais", um marco sem dúvida relevante na história do direito eleitoral português e com início no período vintista. Manuel MonTEIRo, Do Recenseamento Eleitoral em Portugal, Coimbra, Almedina, 2012, pp. 48-50.

166 in Diário das Cortes Geraes e Extraordinarias da Nação Portuguesa, t. VI, Sessão de 11 de Julho de 1822, p. 780.

167 Constituição Politica da Monarchia Portugueza, Lisboa, Imprensa Nacional, 1822, p. 20.

168 Viriato Soromenho MARQUES, “A Constituição de 1822. Uma Filosofia política intempestiva”, in Philosophica 11, Abril de 1998, p. 5.

169 Paulo OTERo, Direito Constitucional Português, vol. I, reimp. da ed. de 2010, Coimbra, Almedina, p. 260.

170 Maurice Hauriou, Précis de Droit Constitutionnel, 2eéd., Paris, Librairie du Recueil Sirey, 1929 , p. 542 . 
eleitoral. Vejamos, pois, o que neste âmbito foi sustentado, desde as Instruções de 31 de Outubro até à Constituição de Setembro de 1822 .

Nas primeiras Instruções, o sufrágio era, como vimos, restrito aos Chefes de família (art. $9^{\circ}$ ), neles não se incluindo os mendigos, os criados de servir que não fossem chefes de família e os incapazes (art. $10^{\circ}$ ). O voto era oral ou secreto, uninominal ou plurinominal, ou só uninominal, consoante o grau em que a eleição se processasse. Havia voto oral no primeiro grau, aquele em que os Chefes de família, nos Concelhos, elegiam os Eleitores de Comarca (art. $12^{\circ}$ ), e secreto no segundo grau, aquele em que os Eleitores de Comarca elegiam os Deputados, e em que o faziam, como observámos anteriormente, escrevendo o nome da pessoa que elegem (art. $21^{\circ}$ ). Na primeira situação, o voto tanto poderia ser uninominal como plurinominal, dependendo do número de Eleitores atribuídos a cada Concelho ${ }^{171}$. Na segunda situação, o voto era sempre uninominal (art. $21^{\circ}$ ), sendo que nos casos em que a Comarca devesse eleger mais de um Deputado, a eleição se repetiria tantas vezes quantas as dos Deputados a eleger. Esta disposição seguramente inspirada na Constituição de Cádiz (art. 88, relativo à eleição dos Deputados) - é reveladora de um processo eleitoral com contornos particulares, cujo conhecimento nos ajuda a compreender, com mais detalhe, toda a lógica do sistema eleitoral de uma parte do período que analisamos. Com efeito, ao determinar que quando os Eleitores de Comarca tenham de eleger mais de um Deputado, "a Eleição (...) se fará separadamente de cada hum" (art. 24), envolvese todo o acto eleitoral de uma complexidade, que na nossa opinião contribuía para conferir um maior rigor na escolha dos Deputados. Um rigor que será reforçado, como veremos, nas Instruções de Novembro e que não pode deixar de ser visto como estando em consonância com a ideia defendida por Silvestre Pinheiro Ferreira, de que quem possui o direito de eleger, o não possui "para proveito individual, mas sim a bem dos interesses da comunidade"172. Uma ideia que podendo implicar para o titular do direito de voto, a presença em várias sessões no âmbito da mesma assembleia eleitoral, demonstra o dever que está associado à função política que lhe foi conferida. Estariamos assim perante mais uma efectiva manifestação da perspectiva funcional, que abrangia todos os envolvidos no processo eleitoral desde a base ao topo. Uma perspectiva, em que as obrigações não só variavam consoante os patamares em que cada um dos intervenientes se encontrava, como aumentavam na medida em que os escalões de participação eram superiores. Este dever funcional tinha neste aspecto um significado expressivo, um significado que será reforçado, como veremos, nas Instruções de 22 de Novembro.

Estas, de facto, não se limitavam a aumentar o número de Juntas Eleitorais e de graus de eleição, uma vez que, seguindo tudo quanto já estava preceituado na Constituição espanhola, vieram definir a necessidade de existência de várias sessões na mesma assembleia eleitoral, não apenas quando estivesse em causa a escolha de mais do que um Deputado, mas também quando se tratasse de escolher os Eleitores que os haveriam de eleger. Neste caso se esclarecia que os Eleitores de Freguesia elegeriam os Eleitores de Comarca "hum depois de

$171 \mathrm{E}$ isso que decorre do art. $3^{\circ}$ das Instruções, que estabelece a proporção entre o número de fogos existentes no Concelho e o número de Eleitores que tem direito a designar.

172 Silvestre Pinheiro FERreIRA, Manual do Cidadão em um Governo Representativo, t. I, Paris, Rey e Gravier, 1834, p. 139. 
outro"173, prescrevendo-se igualmente que os Eleitores de Comarca "procederão á eleição do Deputado, ou Deputados, aos quaes elegerão hum depois de outro"174. No fundo, ao aumentarem o número de graus eleitorais, aumentavam igualmente o número de etapas que seria necessário percorrer para se alcançar a meta. Significa isto, que sem deixarmos de continuar a identificar o sistema eleitoral aqui instituído como um sistema com quatro graus ${ }^{175}$, nos parece ser de assinalar que ele poderia ainda comportar várias sessões, nas assembleias eleitorais do terceiro e do quarto graus. E nesses casos, ou seja, quando nas Juntas Eleitorais de Comarca e nas Juntas Eleitorais de Província, se devesse eleger mais do que um Eleitor de Comarca ou mais do que um Deputado, respectivamente, este sistema poderá ser caracterizado como um sistema de quatro graus, com sessões eleitorais continuadas. Vejamos agora o que se passava, quanto ao modo como o voto era exercido.

$\mathrm{Na}$ primeira assembleia, ou seja, no colégio eleitoral de freguesia ( $\left.1^{\circ} \mathrm{grau}\right)$, os Cidadãos elegem por voto oral, uninominal ${ }^{176}$ ou plurinominal, os Compromissários (art. $51^{\circ}$ ). Na segunda assembleia, referente ao colégio eleitoral dos Compromissários ( $2^{\circ}$ grau), estes elegem por voto oral, uninominal ${ }^{177}$ ou plurinominal, os Eleitores de Freguesia (art. 53 ${ }^{\circ}$. Na terceira assembleia, correspondente ao colégio eleitoral dos Eleitores de Freguesia ( $3^{\circ}$ grau), estes elegem por escrutínio secreto e uninominal os Eleitores de Comarca (art. $73^{\circ}$ ). $\mathrm{Na}$ quarta assembleia, relativa ao colégio eleitoral dos Eleitores de Comarca (4 $\left.{ }^{\circ} \mathrm{grau}\right)$, estes elegem por voto oral e uninominal os Deputados (art. 88 $8^{\circ}$.

Importa, porém, que analisemos com detalhe o que acaba de ser dito, para melhor compreendermos o sistema que vigorava em relação ao voto. E importa que o façamos, atendendo a que a simples identificação do voto como oral, secreto, uninominal ou plurinominal, deixa por evidenciar aspectos que consideramos relevantes para a caraterização do sistema eleitoral em apreciação. Devemos assim, em primeiro lugar, referir que podendo os círculos eleitorais serem plurinominais, e eram-no na esmagadora maioria dos casos, isso não impedia que o voto fosse sempre uninominal nos terceiro e quarto graus. Tal facto iria conduzir a uma pluralidade de votações uninominais fossem essas votações por escrutínio secreto (eleição dos Eleitores de Comarca), fossem elas orais (eleição dos Deputados). O voto só era plurinominal, no primeiro e no segundo graus e em duas situações: quando os Cidadãos ao nível da sua freguesia tinham

173 Art. $73^{\circ}$, das Instruções de 22 de Novembro.

174 Art. $88^{\circ}$, das Instruções de 22 de Novembro.

175 Há quem identifique o sistema eleitoral consagrado nas Instruções de 22 de Novembro, ou seja na Constituição espanhola, como um sistema de "três graus e dois níveis no primeiro grau", entendendo outros apenas classificá-lo como um sistema eleitoral de "três níveis", tendo em atenção as três Juntas eleitorais existentes. Lei eleitoral - Instruções para as eleições dos deputados de 22 de Novembro de 1820 segundo o método espanhol da Constituição de Cádis [Disponivel em http://www.iscsp.ulisboa.pt/ cepp/leis_eleitorais/1820.htm (consultado no dia 29 de Abril de 2017)] e Márcia Regina BERBEL, "A Constituição Espanhola no mundo LusoAmericano (1820-1823)", in Revista de Indias, v. 68, $\mathrm{n}^{\circ}$ 242, 2008, Madrid, p. 231, respectivamente.

176 Previa-se a possibilidade de eleição de apenas um Compromissário, nos casos em que as Freguesias tivessem apenas 20 fogos (art. $43^{\circ}$ ).

177 Nas freguesias que tinham 150 fogos, mas menos de 200, elegia-se apenas um Eleitor de Freguesia (art. $40^{\circ}$ ). 
de eleger mais do que um Compromissário - "cada hum dos Cidadãos designará hum número de pessoas igual ao número dos Compromissários" (art. 51 ${ }^{\circ}$ ), e quando estes tinham de eleger mais do que um Eleitor de Freguesia - "Os Compromissários nomearão o Eleitor, ou Eleitores daquella Parochia" (art. 53). Nas outras duas votações o voto era, como dissemos, uninominal. É certo que em ambos os casos se assegurava a pessoalização da escolha, independentemente do número de escolhas que tivessem de ser feitas, mas não deixa de ser significativo que na eleição dos Eleitores de Comarca e dos Deputados, se vincasse a necessidade de a cada acto, a cada votação, corresponder apenas a eleição de uma pessoa. E aqui residia também uma grande diferença entre a votação plurinominal e uninominal. Quando a votação era plurinominal o votante não deixava de dizer quem queria eleger, mas tinha de o fazer, no mesmo acto, em relação a todos os que deveriam ser eleitos pelo seu círculo eleitoral. De modo distinto, quando a votação era uninominal, mesmo que estivesse em causa a eleição de várias pessoas por aquela assembleia, cada voto apenas servia para eleger um candidato de cada vez.

Mas se estas eram as condições em que o voto se transmitia, convirá ainda compreender a forma como ele se expressava. E convirá compreendê-lo, desde logo para explicarmos a razão que nos leva a falar de voto oral e não de voto público, bem como para percebermos a que nos referimos quando falamos de escrutínio secreto. Comecemos pelo voto oral.

Na eleição dos Compromissários "cada hum dos Cidadãos se aproximará da meza do Presidente, Escrutinadores, e Secretário, e este na sua presença escreverá em huma lista os nomes das ditas pessoas" (art. 51\%). Na eleição dos Deputados, os Eleitores de Comarca "aproximando-se da meza em que se achão o Presidente, Secretário, e Escrutinadores; e o Secretário na presença delles escreverá em huma lista o nome da pessoa, que cada um tiver eleito" (art. $88^{\circ}$ ). Como se percebe o voto era transmitido oralmente à Mesa, apenas à Mesa, devendo cada eleitor dela se aproximar para esse fim, pelo que não estávamos propriamente perante um voto transmitido perante o público. É evidente que se quisermos classificar todo o voto não secreto como voto público, pela circunstância de identificarmos o voto secreto, como aquele "qui s'exerce dans l'anonymat et qui ne permet à personne de connaître le choix de lélecteur"178, o voto de que aqui falamos, sendo um voto transmitido a terceiros, será sempre considerado como público. E sê-lo-á, mesmo que esses terceiros possuam um estatuto especial na assembleia eleitoral. Entendemos, no entanto, que a forma de expressão do voto a que aqui nos referimos é uma forma específica, que não se confunde com o voto dado num qualquer plenário ${ }^{179}$, pelo que consideramos mais adequado falar em voto oral, do que em voto público. Vejamos agora, a particular situação do que se entendia por escrutínio secreto. Quererá a expressão dizer o mesmo que voto secreto?

178 Louis FAVOREU (coord.), Droit constitutionnel, 19e éd., Paris, Dalloz, 2017, p. 537.

179 De que é exemplo o voto dado pelos eleitores nas assembleias eleitorais primárias, previsto no art. $53^{\circ}$ da Constituição de 1822 , para aprovação ou desaprovação dos nomes propostos para Escrutinadores e Secretários da Mesa eleitoral. Perante as propostas feitas pelo Presidente da assembleia, esta "as approvará ou desapprovará por algum sinal, como o de levantar as mãos direitas”. Constituição Politica da Monarchia Portugueza, Lisboa, Imprensa Nacional, 1822, pp. 2425. 
Prescrevia o art. $73^{\circ}$, das Instruções de 22 de Novembro, que o Eleitor de Freguesia elegeria os Eleitores de Comarca "por escrutinio secreto, por meio de bilhetes, nos quaes esteja escrito o nome da pessoa, que cada hum elege", conferindo assim a esta eleição uma forma diferenciada das que verificámos anteriormente. Sucede, contudo, que este "escrutínio secreto" de que aqui se fala tem de merecer entendimento distinto, da disposição constante no art. $21^{\circ}$, das Instruções de 31 de Outubro. Nestas Instruções, definia-se que nas assembleias de segundo grau, aquelas em que os Eleitores de Comarca elegiam os Deputados, "haverá huma Meza separada, na qual cada Eleitor hirá escrever o nome do que elege; e pegando da tira de papel, em que o escreveo, a lançará por sua mão em huma Urna". A expressão "nos quaes esteja escrito o nome da pessoa, que cada hum elege", não tem o mesmo significado da expressão "hirá escrever o nome do que elege". Como facilmente se depreende, enquanto nesta última situação é o eleitor que escreve o seu próprio voto, conferindo-lhe desse modo pleno secretismo, na primeira o voto tanto pode ter sido escrito pelo eleitor, como por uma outra pessoa. O escrutínio era secreto, na medida em que os membros da Mesa não tomavam conhecimento da escolha feita por cada eleitor em concreto, o que não significava que a opção feita pelo eleitor fosse secreta, no caso de ele ter solicitado a outrem que por si escrevesse o nome daquele em quem queria votar. Estávamos afinal perante um voto secreto pouco ou nada secreto, atendendo às particularidades de que se revestia, não sendo seguramente alheia a essas particularidades, a circunstância das Instruções de 22 de Novembro, copiando a Constituição espanhola, terem o cuidado de falar em escrutínio secreto e não em voto secreto.

Este modelo de voto estaria igualmente presente no Projecto de Constituição apresentado às Cortes, no dia 25 de Junho de 1821, sendo estendido aos dois graus eleitorais aí previstos (eleição dos Eleitores de Concelho e eleição dos Deputados), e com a menção de que "a eleição se fará por listas secretas sem dependencia de serem assignadas" (art. 54, do Projecto). Preferia-se a expressão listas secretas, à de escrutínio secreto, mas surgia de forma expressa o esclarecimento de que essas listas não necessitavam de ser assinadas pelo eleitor. Era um esclarecimento que não só fortalecia a perspectiva de que quem não soubesse ler, nem escrever, não estava por isso inibido de exercer o seu direito de votar, como também indicava que o voto não seria considerado nulo na ausência de assinatura. Relevante é quanto a nós o facto de se propor este modelo de voto logo no primeiro grau eleitoral, uma situação inédita, já que neste grau, até então, fosse nas Instruções de 31 de Outubro, fosse nas Instruções de 22 de Novembro, o voto era oral. Na realidade o que o Projecto de Constituição evidenciava era uma clara preocupação em conciliar um progressivo caminho rumo ao secretismo do voto, com a vontade/necessidade, de não afastar dos actos eleitorais os analfabetos. Uma preocupação muito presente nas Cortes Constituintes, em cujos debates se confrontaram duas posições muito claras. De um lado, aqueles que defendendo o voto de quem não sabia ler, nem escrever, o justificava dizendo: "não podemos ser injustos a respeito da geração presente, que tem cooperado grandemente para o estabelecimento do systema constitucional"180; do outro, aqueles que questionando a solução e duvidando da eficácia da conciliação entre o analfabetismo e o secretismo do voto, afirmavam: "ora o eleitor

180 Deputado Miranda, in Diário das Cortes Geraes e Extraordinarias da Nação Portuguesa, Sessão de 17 de Abril de 1822, p. 832. 
que não sabe escrever, como poderá estar seguro de que o nome que desejava e julgava escolher, vai com effeito parar na urna?"181. Uma dúvida a que de forma incisiva Borges Carneiro, responderia: "para eleger bons Deputados, he necessario saber ler, e escrever? Não. O que he necessário he ter bom senso comum, e boas intenções: se não escreve a lista dos nomes pede a quem lha escreva: não ha homem nenhum que não tenha um filho, um amigo, um irmão de quem se he"182.

Esta posição sairia vencedora, reconhecendo-se, porém que a solução a que conduzia não podia deixar de ser transitória pelo que, para o futuro, "todo o que tiver direito de cidadão não póde exercitar este direito, sem saber ler e escrever. Só um descuido e desmazelo reprehensivel he que faz com que os homens ignorem uma cousa que the he tão conveniente"183. E nestes termos seria aprovada uma proposta feita pelo Deputado Fernandes Thomaz, que procurando permitir que os analfabetos votassem no imediato, indicava que "todos os que actualmente tiverem 17 annos de idade, ou dahi para baixo, e para o futuro, não poderão votar nas eleições, ainda que cheguem a idade competente, em quanto não souberem ler, $e$ escrever" ${ }^{\prime 84}$. Estávamos perante uma solução, mais tarde consagrada no art. $33^{\circ}$, VI, do texto constitucional, no qual se esclarecia não poderem votar: "os que para o futuro, em chegando á idade de vinte e cinco annos completos, não souberem ler $e$ escrever, se tiverem menos de dezesete quando se publicar a Constituição"185. E assim ficavam instituídos três regimes quanto à capacidade eleitoral activa: um regime definindo que os homens com pelo menos 25 anos, ou que tendo apenas 20 anos, mas fossem casados, poderiam votar. Um regime especial, admitindo que quem tivesse entre os 17 e os 25 anos à data da aprovação da Constituição e não tivesse casado aos 20 , poderia votar uma vez chegado à idade legal do voto (25 anos). E que o poderia fazer, mesmo que ainda não soubesse ler, nem escrever. Por fim, o regime que indicava que quem tivesse menos de dezassete anos só poderia votar quando atingisse os 25 anos, desde que soubesse ler e escrever ${ }^{186}$. Estava salvaguardada a situação dos analfabetos que votariam por escrutínio secreto, mas assumia-se que a monarquia constitucional tendo como objectivo que a instrução chegasse ao maior número de homens, faria depender a futura entrada no colégio eleitoral aos cidadãos que lessem e que escrevessem. Fácil é depreender que só nessas futuras circunstâncias, o voto secreto poderia ser efectivamente secreto. Até lá, e como esclarecia o art. 52 ${ }^{\circ}$, da Constituição, "os moradores de cada concelho que tem voto nas eleições, levando escritos em listas os nomes e occupações das pessoas em quem votão para Deputados" designariam a composição das Cortes, sendo que essa designação tanto caberia aos analfabetos, como às pessoas que já não o fossem.

181 Deputado Franzini, ibidem, p. 833.

182 Deputado Borges Carneiro, ibidem, p. 834.

183 Deputado Miranda, ibidem, p. 832.

184 Deputado Fernandes Thomaz, ibidem, p. 838.

185 Constituição Politica da Monarchia Portugueza, Lisboa, Imprensa Nacional, 1822, p. 17.

${ }^{186}$ Consideramos interessante salientar que com esta disposição, os Constituintes portugueses seguiam a disposição da Constituição espanhola, segundo a qual se suspenderia o exercício dos direitos de cidadania, para os espanhóis que a partir de 1830 não soubessem ler, nem escrever. Aî se prescrevia, que "Do anno de 1830 por diante deverão saber ler e escrever os que de novo entrarem no exercicio dos direitos de Cidadão". Art. 25, 6, da Constituição espanhola de 1812 , in Constituição Política da Monarquia Hespanhola, op. cit., p. 11. 
Percebemos então que o voto secreto definido pela primeira Constituição portuguesa, seguindo aliás o modelo previsto no $3^{\circ}$ grau eleitoral estabelecido pela Constituição espanhola (eleição dos Eleitores de Comarca), em nada se assemelha à ideia que hoje fazemos desta qualidade de voto e em nada se equipara às situações em que, na actualidade, algumas pessoas pedem ajuda para exercerem o seu direito de votar ${ }^{187}$. Pensamos, pois, que devemos ter em conta esta especificidade quando falamos do voto secreto na Constituição de 1822 pelo que, sem querermos questionar a bondade da "opção vintista e inovadora do sufrágio secreto" 188 , dificilmente poderemos deixar de realçar que o modelo de voto secreto então adoptado, não só não era muito inovador, como não era muito secreto. E não o era, já que permitia a outras pessoas tomarem conhecimento da opção feita pelos eleitores analfabetos.

Há ainda um dado que importa assinalar e que se prende com o voto plurinominal na escolha dos Deputados. Enquanto as Instruções, quer de Outubro, quer de Novembro, previam nessa escolha o voto uninominal, e um voto uninominal a várias voltas, a Constituição passou a estabelecer uma objectiva correspondência entre o voto plurinominal e a organização também plurinominal de cada divisão eleitoral. Não obstante, como veremos no ponto seguinte, se passar a prever a possibilidade de uma segunda volta nas eleições, manifestavase uma preocupação em simplificar todo o processo eleitoral, simplificação essa que passava pela indicação de todos os nomes que deveriam ser eleitos, logo no momento da votação inicial. É isso que decorre do já citado art. 52 ${ }^{\circ}$, ao prescrever que cada uma das listas de voto entregues pelos eleitores deverão "encerrar o numero dos Deputados que tocão áquella divisão eleitoral, e mais outros tantos para os substituírem". A escolha individualizada dos Deputados não deixava de existir, mas os boletins de voto deveriam conter tantos nomes, quantos os que deviam ser eleitos pela divisão eleitoral em causa. Os nomes e também as ocupações daqueles que se pretendia eleger, não só para se perceber se o voto tinha incidido em alguém inelegível (arts. $34^{\circ}$ e $35^{\circ}$ ), como para fazer cumprir um dos requisitos que os constituintes tinham considerado mais relevantes e que traduzia a ideia de que "só do homem que tem meios para substir, he que se póde esperar, que seja amante da sua pátria"189. Ou seja, só os que têm "para se sustentar renda sufficiente, procedida de bens de raiz, commercio, industria, ou emprego" (art. 34\%), podem ser eleitos Deputados. A Constituição não recuperaria a condição capacitaria prevista nas Instruções de 31 de Outubro de 1820, mas não abandonava a condição censitária já por elas definida, para os representantes da Nação. Se já estava clara a percepção de que "the representation of people does not necessarily mean the representation of all

187 Situação prevista, por exemplo, na Lei Eleitoral da Assembleia da República portuguesa, que no seu art. $97^{\circ}$, define as circunstâncias em que o eleitor afectado por doença ou deficiência física notória pode votar acompanhado e em que o acompanhante fica vinculado a um dever de sigilo absoluto. Lei Eleitoral da Assembleia da República [Disponivel em: http://www.cne.pt/content/lei-eleitoral-da-assembleia-da-republica (consultado no dia 18 de Maio de 2017)].

188 Maria Antonieta CRUZ, "Debates Parlamentares em torno do Direito de Voto no Portugal Oitocentista", in F. Ribeiro da Silva, M. Antonieta Cruz, J. Martins Ribeiro, H. Osswald, (org.), Estudos em Homenagem a Luis António de Oliveira Ramos, vol. I, Porto, Faculdade de Letras da Universidade do Porto, 2004, pp. 444.

189 Deputado Trigoso, in in Diário das Cortes Geraes e Extraordinarias da Nação Portuguesa, Sessão de 10 de Outubro de 1821, p. 2597. 
people"190, evidenciada pelo conjunto de pessoas que não tinham direito de voto (art. 33, II, III, IV e V), ficava também explícito que a função de representar o povo e de em seu nome legislar era tarefa que apenas deveria caber a alguns. Os Constituintes não tinham esquecido as palavras de Montesquieu, quando de forma lapidar esclareceu: "o povo é admirável quando escolhe aqueles aos quais deve delegar uma parte da sua autoridade. Mas seria ele capaz de conduzir um negócio, conhecer os lugares, as oportunidades, os momentos, e aproveitar-se disto? Não, não seria capaz"191.

\section{O critério de atribuição dos mandatos.}

Aqui chegados, convirá ter presente que o conhecimento sobre a evolução do sistema eleitoral vintista ficaria incompleto sem analisarmos o critério de atribuição dos mandatos. Sendo parte de um todo, este critério é também revelador das preocupações existentes desde as Instruções de 31 Outubro de 1820, na construção do novo sistema eleitoral. Vejamos, pois, como se apuravam os eleitos no sistema eleitoral por graus, para percebermos se alguma linha de continuidade se manteve no sistema de eleição directa.

Nas primeiras Instruções, apenas com dois graus eleitorais, tanto os Eleitores de Comarca, como os Deputados, eram eleitos por maioria simples, sendo que em caso de empate se procederia a sorteio entre os mais votados (arts. $13^{\circ}$ e $25^{\circ}$ ). Sendo, no entanto, a eleição dos Deputados feita "um por um", o apuramento de cada eleito obedecia a igual critério (art. $21^{\circ}$ ), o que significava que por cada uma das votações registadas, deveria existir igual número de operações de contagem dos votos. Esta particular situação iria estar mais presente nas Instruções de 22 de Novembro, uma vez que aqui este tipo de escrutinio se alargava aos Eleitores de Comarca.

Mas estas novas Instruções faziam ainda combinar vários critérios de eleição e vários critérios de apuramento dos resultados. No primeiro grau, os Compromissários eram eleitos por maioria simples, sendo o apuramento dos eleitos feito por ordem decrescente (arts. $51^{\circ}$ e $52^{\circ}$ ). No segundo grau, os Eleitores de Freguesia eram eleitos por maioria absoluta e o apuramento dos eleitos obedecia ao critério anterior (art. 53\%). No terceiro grau, os Eleitores de Comarca eram igualmente eleitos por maioria absoluta, mas neste caso já existia a previsão de uma segunda volta entre os dois mais votados, caso nenhum deles tivesse obtido aquela maioria na primeira volta. Nesta segunda volta, venceria o que tivesse maioria simples. Importa, todavia, esclarecer que como a eleição era feita "hum depois de outro", a possibilidade de realização de uma segunda volta existia para a eleição de cada um dos Eleitores de Comarca, individualmente considerados. Quer isto dizer que tendo de ser eleitos, por exemplo, três Eleitores, se poderiam ter de realizar seis eleições, duas por cada um, caso nenhum deles tivesse conseguido a maioria absoluta na primeira votação respectiva (art. $74^{\circ}$ ). Igual procedimento se verificava no quarto grau, para a eleição dos Deputados efectivos (art. $8^{\circ}$ ), repetindo-se obrigatoriamente esta operação eleitoral, na

190 Hanna Fenichel Pitkin, The Concept of Representation, Berkeley, University of California Press, 1972, p. 190.

191 Montesquieu, O Espirito das Leis, trad. de Cristina Murachco, São Paulo, Martins Fontes, 1996, pp. 20-21. 
eleição dos Deputados substitutos (art. 90). Estávamos diante um processo que tentando conciliar a exigência de maioria absoluta para cada um dos eleitos e para cada um dos substitutos, com uma operação de escrutínio e de apuramento individuais, conduzia a que a eleição pudesse decorrer durante vários dias e durante várias horas, por cada um dos dias envolvidos. A opção pela maioria absoluta, procurando que os eleitos representassem o maior número possivel de votos, inspirava-se seguramente nas soluções adoptadas pela Igreja séculos antes. Como refere Pierre Martin, " $l$ ' introduction de l'exigence de majorité absolue est apparue, sous linfluence de l'Eglise catholique"192, uma Igreja que tinha introduzido "several innovations in voting procedures in the Middle Ages, including qualified-majority rule", numa época em que "this and other qualified - majority rules also saw use in several Italian communes of the Middle Ages"193. Ora somando a esta opção, um minucioso e demorado processo de votação, de escrutínio e de apuramento, as eleições poderiam, como dissemos, prolongar-se por largo período de tempo. Uma consulta dos Diários do Governo da época dános esse testemunho explicando, por exemplo, que a eleição de 25 Deputados pela Província do Minho, demorou sete dias, alguns dos quais com várias sessões seguidas, de manhã e de tarde ${ }^{194}$. Aí se constata como várias foram as vezes em que houve lugar a segundos escrutinios: "A huma hora sahio eleito com 47 votos em segundo Escrutínio, porque o primeiro não deo eleição legítima o Ilustrissimo Senhor Manoel Martins do Couto, natural desta Cidade, Doutor em Leis pela Universidade de Coimbra"; "A's tres horas sahio eleito em segundo Escrutinio com 38 votos o Ilustrissimo Senhor Doutor António Ribeiro da Costa, natural desta Cidade"195. A caminhada para a eleição era, pois, longa, conduzida por uma Mesa que tinha a função de responder às dúvidas que sistematicamente se colocavam, numa Assembleia a quem cabia, em primeira e última instância, dirimir conflitos ${ }^{196}$, tal como definia o art. $85^{\circ}$, das Instruções.

Era um intrincado processo, pelo que sem surpresa verificamos que logo no Projecto de Constituição, o mesmo em que se retomam as eleições em dois graus, se propunha que os Eleitores de Comarca e os Deputados passassem a ser eleitos por maioria simples. Seriam eleitos os Eleitores de Comarca e os Deputados, que obtivessem maior votação, sem necessidade de qualquer outro específico critério.

Seria, no entanto, outro o entendimento da Constituição, que ao instituir a eleição directa dos Deputados não abandonou a necessidade de estes obterem a

192 Pierre MARTin, Les systèmes électoraux et les modes de scrutin, $3^{\mathrm{e}}$ ed., Paris, Montchrestien, 2006, p. 38.

193 Josep M. COLOMER e Iain MCLEAN, "Electing Popes: Approval Balloting and Qualified Majority Rules", in Journal of Interdisciplinary History 29/1, Summer, 1998, pp. 2 e 9; Drahomír SUCHÁNEC, "Historical and Legal Milestones of Medieval Papal Elections", West Bohemian Historical Review 1, 2012, pp. 27-40 [Disponivel em: http://hdl.handle.net/11025/11384 (consultado no dia 18 de agosto de 2017)].

194 Diários do Governo, $\mathrm{n}^{\circ} \mathrm{s}$ 2, 3, 4, 6 e 8, dos dias 2, 3, 4, 6 e 9 de Janeiro de 1821, respectivamente.

195 Diário do Governo, n ${ }^{\circ}$ 3, de 3 de Janeiro de 1821, p. 3.

196 De que é exemplo, a situação transcrita no Diário do Governo, de 2 de Janeiro de 1821, no qual se lê: "Depois tratou-se da questão se os Desembargadores das duas Relações de Lisboa e Porto (exceptuando os que tem varas civeis ou criminaes) podem ser eleitos por esta Provincia do Minho, sendo della naturaes? Resolveo-se negativamente por huma maioria de 3 votos”. Cf. Diário do Governo, $\mathrm{n}^{\circ} 2$, de 2 de Janeiro de 1821, p. 3. 
maioria absoluta dos votos, na divisão eleitoral pela qual concorriam. Estavam nesta questão em sintonia, não só com as opções seguidas pela Constituição espanhola de 1812, como ainda com as preferências dos franceses. Estes, desde a Revolução, "ont marqué leur préference pour un mode de scrutin à plusieurs tours, permettant à l'élu de represénter la majorité des électeurs de la circonscription"197. E essa preferência seria vincada na Constituinte, aí se afirmando que "seria uma admiração para a Europa inteira, que da pluralidade relativa podessem resultar Deputados para representantes de uma nação; seria decerto um absurdo. Isto seria dar aso a que uma facção podesse representar a Nação; seria dar occasião a que os inimigos da liberdade entrassem nessa facção"198.

Sucede, porém, que se a maioria absoluta determinava a eleição, o processo de escrutínio e de apuramento dos resultados era feito a três niveis, em três assembleias diferentes. No primeiro nível, nas chamadas assembleias primárias, aquelas que correspondiam às freguesias de cada Concelho e nas quais os Cidadãos votavam, eram apurados os votos alcançados por cada um dos nomes escolhidos para Deputados (art. $55^{\circ}$ ). No segundo nivel, na casa da Câmara e perante a relação dos nomes votados em cada assembleia primária, dos nomes e da respectiva votação, apuravam-se os votos por todos obtidos, em todo o Concelho (art. $61^{\circ}$ ). No terceiro nível, na casa da Câmara da cabeça da divisão eleitoral, procedia-se ao escrutínio dos votos recolhidos em todos os Concelhos da divisão eleitoral e seriam declarados Deputados efectivos e substitutos, aqueles que tivessem recebido a maioria absoluta dos sufrágios, em toda a divisão eleitoral. Não obstante todos os futuros Deputados, tanto efectivos, como substitutos, necessitarem de maioria absoluta para serem declarados eleitos, seriam efectivos aqueles que tivessem mais votos (art. 63). Se restassem lugares para preencher, pelo facto de não terem existido candidatos em número suficiente a obterem a maioria absoluta, procedia-se a uma segunda volta das eleições apenas para completar os assentos em falta (art. 64\%). Neste caso, os eleitores seriam chamados de novo às assembleias primárias (art. 66 $6^{\circ}$ ), devendo escolher de entre uma lista, "que contenha tres vezes o número que faltar, formada dos nomes daquelles que tiverem mais votos" (art. 64\%). Nesta segunda volta, repetirse-iam todas as operações de escrutínio e de apuramento verificadas na primeira volta, bastando para a eleição a maioria simples dos votos.

E deste modo, se estabeleceria um critério de atribuição dos Deputados a cada divisão eleitoral, que se distinguia em múltiplos aspectos dos critérios anteriormente previstos nas Instruções eleitorais de 31 de Outubro e de 22 de Novembro. Pouco mais de dois anos se tinham passado após a revolução de Agosto de 1820, mas um longo percurso político tinha sido feito num país pouco ou nada dado a amplas discussões politicas e a processos eleitorais como aqueles que entretanto se tinham verificado. É certo que foi um percurso depressa interrompido, "não tendo a Constituição chegado a funcionar verdadeiramente"199,

197 Jean-Marie CotTeret e Claude Emeri, Les Systèmes Électoraux, 6e éd., Paris, PUF, 1994, p. 49.

198 Deputado Margiochi, in Diário das Cortes Geraes e Extraordinarias da Nação Portuguesa, Sessão de 1 de Maio de 1822, p. 8.

199 Vital Moreira, Sebenta de Direito Constitucional, Porto, Faculdade de Direito da Universidade Lusíada - Norte, 2016, p. 147 (texto policopiado). 
mas isso em nada anula o papel pioneiro do sistema eleitoral vintista por ela consagrado, na história do direito eleitoral português.

\section{CONCLUSÕES.}

A Revolução Liberal do dia 24 de Agosto de 1820 surge em manifesta ruptura com o quadro constitucional do Antigo Regime. É por demais evidente que a sua primordial intenção era a de recuperar o parlamento perdido, i. e., voltar a convocar as Cortes instituídas na Idade Média e interrompidas no final do século XVII. No início do ano de 1820, Liberato Freire de Carvalho considerava as Cortes portuguesas como a "couza mais sagrada e importante que tem a nossa Monarquia e da qual sempre dependeram e ainda hoje, mais do que nunca, dependem nossas Liberdades". No entanto, o regresso ao passado veio atiçar a vetusta tensão constitucional entre o princípio monárquico e o princípio representativo, tornando-se peremptório, antes de mais, decidir quem seria o novo titular da soberania.

Girando em torno desta velha questão da titularidade do poder político, o debate e a pugna politica vintistas acabaram por impor a mudança de um encanecido modelo representativo historicista para um novo modelo representativo iusracionalista. Por outras palavras, passou-se da constituição estamental da Idade Média para a constituição representativa moderna. O parlamento assume-se, agora, como o órgão máximo representativo da soberania e legitimador do poder político, em detrimento de grande parte da autoridade do monarca. Por isso, embora mantendo a velha designação e múltiplas afinidades com as Cortes tradicionais, temos que reconhecer que, entre 1820 e 1822, foi instituído um órgão parlamentar novo e diferente em múltiplos aspetos em relação ao seu homólogo medieval (afinidades e diferenças que não é possivel nem oportuno estar agora a esmiuçar).

O que neste estudo importa concluir, tentando dar resposta à questão que deixamos em aberto na introdução, são as rupturas e continuidades verificadas no modo de escolha dos representantes do reino/nação às Cortes nesse período de 1820-1822, em confronto directo com o passado eleitoral dos séculos XIIIXVII. Ou seja, por um lado, compreender em que medida as decisões adoptadas continham linhas de continuidade, com aquilo que entre nós se tinha verificado no âmbito eleitoral durante a Idade Média; por outro, perceber o que de original os vintistas trouxeram para a edificação de um sistema eleitoral que correspondesse às exigências e ambições do novo regime.

Nesse sentido, conforme supra explanado, entendemos indagar: (i) se voto oral significava o mesmo que voto público; (ii) se escrutinio secreto pressupunha o mesmo que voto secreto; (iii) se a eleição uninominal dos Deputados obedecia a regras específicas; (iv) se na mesma assembleia eleitoral, poderiam ou não coexistir várias sessões eleitorais; $(\boldsymbol{v})$ se a votação plurinominal na eleição dos Deputados, consagrada na Constituição de 1822, tinha correspondência no apuramento dos eleitos. Pareceu-nos que a compreensão do sistema eleitoral vintista, não só não dispensava este tipo de análise, como igualmente convidava a que tentássemos compreender qual o verdadeiro significado das Instruções de 31 de Outubro, tantas vezes desvalorizadas, ou até ignoradas, quando na realidade, apesar de substituídas na eleição das Cortes constituintes, voltaram a ver a luz 
do dia no Projecto de Constituição. É, pois, em função destes passos, que podemos agora apresentar algumas conclusões. vintista:

Continuidades do sistema eleitoral consuetudinário para o sistema eleitoral

(i) Verifica-se um traço de objectiva continuidade na preocupação com a escolha para as Cortes de representantes qualificados, de "homens bons e entendidos". Uma preocupação traduzida pelos vintistas, inicialmente, na eleição por graus e, posteriormente, mantida na exigência de que os Deputados possuíssem meios de subsistência capazes de lhes garantir independência nas deliberações que deveriam adoptar. Falamos de algo, que, sendo comum a todo o pensamento liberal, tem uma matriz anterior ao liberalismo e cuja manifestação concreta pode ser encontrada no período medieval português.

(ii) Outro aspecto de continuidade, que merece ser assinalado é o do voto oral, previsto nas Instruções de 31 de Outubro e nas de 22 de Novembro. Constata-se que o modo como previam o seu exercício, era em tudo igual ao praticado entre nós nos finais da Idade Média e princípios da Idade Moderna.

(iii) Embora em termos diferentes do que ficou preconizado nas Instruções de Outubro de 1820 -como diremos de seguida- a preocupação com o voto secreto é também um vetor de continuidade entre os dois sistemas eleitorais em confronto.

Inovações na passagem do sistema eleitoral consuetudinário para o sistema eleitoral vintista:

(i) A Junta Governativa estabelecida após a revolução de Agosto de 1820, denotou aproximar-se mais do modelo eleitoral definido pela Constituição francesa de 1791, que previa a eleição dos Deputados em dois graus. Fê-lo, seguindo o que considerava ser a solução que melhor se adaptava à realidade portuguesa, dividida entre os que queriam a convocação de eleições de forma directa e os que, reivindicando uma eleição com mais graus, entendiam que o modelo espanhol melhor se adaptava às suas pretensões.

(ii) As Instruções de 31 de Outubro de 1820, foram a primeira lei eleitoral portuguesa a instituir o voto secreto, ao definirem que na eleição dos Deputados, os Eleitores de Comarca deveriam escrever o nome da pessoa escolhida. Estatuindo que em cada assembleia eleitoral, "haverá huma Meza separada, na qual cada Eleitor hirá escrever o nome do que elege; e pegando da tira de papel, em que o escreveo, a lançará por sua mão em huma Urna", estas Instruções são, em Portugal, pioneiras neste tipo de voto.

Concluímos não existir qualquer semelhança entre esta situação e aquela que estava prevista na Constituição de Cádis, na eleição dos Eleitores de Comarca, pelos Eleitores de Freguesia, nem na que ficaria estabelecida na Constituição de 1822, na eleição dos Deputados. Ao falarem em escrutínio secreto, ambas as Constituições pretendem apenas salvaguardar o secretismo da opção feita pelo eleitor perante os membros da mesa eleitoral, não colocando em causa a possibilidade de redacção do 
boletim poder ser feita por pessoa diferente do próprio eleitor, ainda que a seu pedido. Deste modo se garantia a possibilidade, dos analfabetos poderem votar.

(iii) Quer as Instruções de 31 de Outubro, quer as de 22 de Novembro (Constituição de Cádis), definiam o voto uninominal na eleição dos Deputados, "hum depois de outro", e faziam-no mesmo que vários fossem os Deputados a eleger por cada eleitor e mesmo quando só fosse eleito quem obtivesse a maioria absoluta dos votos (Instruções de 22 de Novembro), o que poderia conduzir à realização de várias sessões eleitorais, no decurso da mesma assembleia eleitoral.

(iv) $\mathrm{Na}$ Constituição de 1822, o voto na eleição dos Deputados passará a ser directo -seguindo, neste aspecto, o que estava definido na Constituição americana de 1787 para a eleição da Câmara dos Representantes- e plurinominal, devendo as listas em que os nomes de cada um dos escolhidos estavam inscritos assinalar ainda as suas ocupações. Procurava-se deste modo garantir que os votados não se incluíam no rol dos inelegiveis. No entanto, se o voto era plurinominal, o apuramento dos eleitos continuava a ser uninominal, mantendo-se assim o critério estabelecido nas Instruções de 31 Outubro e nas de 22 de Novembro. A eleição já não se fazia "hum depois de outro", mas a contagem dos votos e a posterior determinação dos eleitos seguia as regras estabelecidas na Constituição de Cádis. Esta conjugação entre o voto plurinominal e o apuramento uninominal, consubstancia uma inovação da Constituição de 1822, face ao que até então tinha sido seguido pelo direito eleitoral português.

(v) Uma outra inovação da Constituição de 1822, refere-se à estatuição de uma segunda volta. Ao definir que só seria eleito Deputado quem obtivesse maioria absoluta -conservando neste particular as disposições das Instruções de 22 de Novembro- a Constituição estabelecia que na segunda volta bastaria a maioria relativa para a eleição. Ainda que a essa segunda volta se devesse apresentar o triplo de nomes dos lugares a preencher -escolhidos a partir dos não eleitos, que tivessem recolhido mais votos- avançava-se para uma clara simplificação do método de eleição, face ao que tinha sucedido na eleição das Cortes constituintes.

(vi) Por último, devemos realçar o facto de a Constituição de 1822 positivar como norma constitucional a necessidade dos detentores do direito de voto se encontrarem inscritos num "livro de matrícula eleitoral", bem como a obrigatoriedade de esse livro estar presente nas assembleias eleitorais. Tal circunstância permite-nos concluir, que os eleitores, nessa específica qualidade, passavam a receber tratamento constitucional distinto daquele que era reservado aos cidadãos geralmente considerados. Ao estipular o recenseamento eleitoral, a Constituição de 1822 diferenciava-se de outras soluções constitucionais que faziam depender o direito de ser eleitor à inscrição no município de residência, dos titulares do estatuto de cidadania activa, nas listas da Guarda Civil (Constituição francesa de 1791, Título III, Cap. I, Secção II, Art. $2^{\circ}$ ), ou à definição da qualidade de Cidadão domiciliado nas freguesias (Constituição de Cádiz, Título II, Cap. IV, Arts. 18 a $23^{\circ}$ e Título III, Cap. III, art. $35^{\circ}$ ). 
Com mais ou menos influência de outros textos constitucionais, recuperando, com adaptações, aquilo que do passado entenderam recuperar, construindo gradualmente o que consideraram de novo dever construir, os vintistas deram um imenso contributo para a fundação de um sistema eleitoral, cuja dimensão e alcance se mantêm. Por isso, não será caso raro encontrar paralelo entre algumas decisões legislativas vintistas e o que já era praticado em tempos muito recuados da Idade Média e alvores da Moderna. Por mais inovadoras que sejam as reformas saídas de uma revolução, o Direito não surge por mera inspiração "divina" das mentes iluminadas que dominam um determinado espaço geográfico do planeta num determinado período do fio cronológico da humanidade. Fechamos com o célebre brocardo de Bernardo de Chartres (século XII), repercutido por Isaac Newton (1676), "se eu consegui ver mais longe, foi porque estava sentando em ombros de gigantes".

Enviado el (Submission Date): 12/09/2017

Aceptado el (Acceptance Date):16/11/2017 